\title{
Study on the Influence of Closed-Cell Aluminum Foam on the Impact Performance of Concrete Pier after Equal Replacement with Stainless Steel Reinforcement
}

\author{
Xiwu Zhou $\left(\mathbb{D}\right.$, Honglong Zhang $\left(\mathbb{D}\right.$, Wenchao Zhang ${ }^{(D)}$, and Guoxue Zhang $(\mathbb{D}$ \\ School of Transportation and Civil Engineering \& Architecture, Foshan University, Foshan, China \\ Correspondence should be addressed to Honglong Zhang; 1942516816@qq.com
}

Received 7 February 2020; Accepted 16 June 2020; Published 18 July 2020

Academic Editor: Davide Palumbo

Copyright (c) 2020 Xiwu Zhou et al. This is an open access article distributed under the Creative Commons Attribution License, which permits unrestricted use, distribution, and reproduction in any medium, provided the original work is properly cited.

\begin{abstract}
In this study, the impact test of two groups of reinforced concrete piers protected by closed-cell aluminum foam is carried out by using the ultrahigh drop hammer impact test system. The purpose of this study is to explore the impact resistance and protective performance of closed-cell aluminum foam under the impact load on the concrete bridge pier after replacing the ordinary reinforcement with stainless steel reinforcement. The study results show that the impact force is related to the overall stiffness of the specimen, as well as to the failure mode. When the impact velocity is less than $1.42 \mathrm{~m} / \mathrm{s}$, the closed-cell aluminum foam is in an elastic or yielding stage. The change rate of impact force (231 and 97.5, respectively), tip displacement ( 33.5 and 18, respectively), and ultrasonic damage rate of the concrete in the two groups of specimen is relatively small, while the change rate of the two groups of specimen remains approximately consistent. In addition, when the impact is greater than $1.42 \mathrm{~m} / \mathrm{s}$ and the closed-cell aluminum foam is in the densification stage, the change rate of the impact force (increase from 231 to 819 and from 97.5 to 984.5 ), the tip displacement (increase from 33.5 to 67 and from 18 to 62), and ultrasonic damage rate of concrete are larger, which results in an increase in the dynamic response of the structure.
\end{abstract}

\section{Introduction}

With the development of transportation industry, traffic accidents, such as ship collision with bridge piers, car collision with guardrails, and superhigh vehicle collision with pedestrian overpasses, occur frequently, resulting in significant economic losses [1-3]. A reinforced concrete (RC) pier is an integral load-bearing component of bridge structure, and its impact resistance is very key to the overall safety of concrete structure [4-6]. Due to the excellent impact energy consumption of closed-cell aluminum foam and strong corrosion resistance of stainless steel reinforcement, it is of great significance to study the protective performance of closed-cell aluminum foam under the impact load on the concrete piers after replacing the ordinary reinforcement with stainless steel reinforcement of equal strength, as this can provide a useful reference for the design of reinforced concrete structures in impact resistance design [7-10].
At present, research regarding reinforced concrete members under impact load performed throughout the world mainly focuses on three aspects: theoretical analysis, experimental research, and numerical simulation. Wang considered the influence of axial force on the lateral impact resistance test of RC columns, and the results showed that the shear failure and bending failure of RC columns may occur under the action of lateral impact load, while the bending failure tends to occur with the increase of axial compression ratio [11]. Additionally, Li et al. [12] used finite element method analysis ANYSYS/LS-DYNA to study the dynamic response of reinforced concrete columns under the impact of rigid sphere, and the results showed that it is reasonable and effective to use the bond-slip separate model to simulate the dynamic response of reinforced concrete columns; Zhou and Zhang [13, 14]studied the impact performance test of a stainless steel reinforced concrete pier, via which the maximum impact force of the pier specimen was determined. The test results showed that the stainless steel 
reinforced concrete pier specimen possessed strong ductility, energy absorption capacity, and impact resistance under the impact load. Due to the strong deformation and energy absorption characteristics of closed-cell aluminum foam, in many cases aluminum foam is introduced to the field of impact resistance of bridge piers as an energy dissipation buffer material, and the dynamic response of aluminum foam to the protection of bridge piers under impact load is studied and analyzed so as to reveal the energy dissipation buffering mechanism of aluminum foam. At present, research regarding closed-cell aluminum foam performed throughout the world mainly focuses on static and dynamic mechanical properties. The results of these studies have shown that there are three distinct stages in the compression process of closed-cell aluminum foam, namely, linear elastic stage, plastic platform stage, and densification stage $[15,16]$. Upon observing these three stages, it is found that a high and wide platform is present in uniaxial compression experiments involving closed-cell aluminum foam. During the compression process, a large amount of energy is absorbed by the stage under approximate constant stress. The longer the platform is, the stronger its energy dissipation capacity will be [17-19]. In order to better evaluate the energy absorption capacity of aluminum foam, Zeng and Alejano $[20,21]$ proposed an energy efficiency curve and an ideal energy efficiency curve. The results of the study showed that the ideal energy absorption efficiency of the aluminum foam material may exceed 0.8 , and the maximum energy absorption capacity can reach $3430 \mathrm{~kJ} / \mathrm{m}^{3}$. In addition, scholars throughout the world have studied the closed-cell aluminum foam by the drop hammer impact test and Hopkinson bar test and have attained a further understanding of the dynamic compression performance and impact resistance of closed-cell aluminum foam. Li et al. [22] studied the dynamic compressive properties of closed-cell aluminum foam, and the study results showed that the stress-strain curves of closed-cell aluminum foam under high-speed compression were the same as those under quasistatic conditions. Li et al. [23] studied the critical conditions for the protection of closed-cell aluminum foam under low velocity impact, and the results showed that when the impact velocity was lower than the critical impact speed, the stress of the aluminum foam would not exceed the compression stress of the platform. Foam aluminum with high porosity can greatly reduce the shock response speed and has a good protective effect. Lan et al. [24] analyzed the energy absorbing ability and impact resistance of closed-cell aluminum foam, reviewed the research progress of the influence of strain rate and impact velocity on the energy absorption characteristics of aluminum foam, and explained the possible influences. Sun et al. [25] studied the dynamic response of aluminum foam sandwich panels under blast impact. The results show that the change of material is highly sensitive to impact strength, laminates, and gradient of aluminum foam core. Wang et al. [26] studies the antiriot performance of aluminum foam sandwich panels. The results show that under the condition of keeping the thickness of the total laminate unchanged, increasing the thickness of the backboard at a relatively low blasting strength is conducive to improving the blast resistance. Sun et al. [27] studied the behavior of aluminum foam sandwich plate under low velocity impact. The results show that the density gradient of foam aluminum sandwich has significant effect on the failure and deformation of the sandwich plate. Zhang et al. [28] carried out a drop hammer loading test on the lateral impact resistance of RC bridge pier model and analyzed the influence of the buffer device on the dynamic response of the specimen. Xu [29] carried out the pendulum impact test on the bridge pier with a closed-cell aluminum foam protection device and then compared and analyzed the influence law of aluminum foam on the bridge pier. In the above studies, the protective performance of closed-cell aluminum foam is mainly analyzed from the perspective of energy absorption, while less attention is paid to the potential threat to the safety of protection caused by the rapid increase of stress resulting from the compaction. Meanwhile, there have been few reports on the use of closed-cell aluminum foam as an energy absorbing material to protect reinforced concrete bridge piers in combination with the structural response speed. The study of the entire process of the impact of protective materials requires further discussion and analysis.

Taking the engineering application of stainless steel reinforced concrete piers of the Hong Kong-Zhuhai-Macao Bridge as the research background, the present paper adopts the domestic advanced ultrahigh dropping hammer impact test system, uses closed-cell aluminum foam as a pier protection device, carries out horizontal impact tests on the concrete piers after equal-strength replacement with stainless steel reinforcement protected by the closed-cell aluminum foam, and studies the influence of the closed-cell aluminum foam on the impact damage of concrete piers after equal-strength replacement with stainless steel reinforcement under the effect of horizontal impact loading.

\section{Test Overview}

2.1. Design of Specimen. In order to study the impact resistance after equal-strength replacement with stainless steel under the effect of impact load under the protection of closed-cell aluminum foam, the double-column round pier is used as the test prototype in this paper, and four reduced scale models are designed with a scale of $1: 5$, as shown in Figure 1. The column cross section of the specimen is $340 \mathrm{~mm}$ in diameter and $2,200 \mathrm{~mm}$ in height. The longitudinal reinforcement of the specimen consists of an S2304 duplex stainless steel bar and HRB400 ordinary steel bar produced by the French UGITECH company. The stirrup is a grade I ordinary steel bar HPB300, with a diameter of $8 \mathrm{~mm}$ and spacing of $50 \mathrm{~mm}$. The reinforcement is welded, and the concrete strength is $\mathrm{C} 40$. The protective materials used in this test are closed-cell aluminum foam, with a length of $210 \mathrm{~mm}$, width of $100 \mathrm{~mm}$, respective thicknesses of $50 \mathrm{~mm}$ and $100 \mathrm{~mm}$, and density of $0.4 \mathrm{~g} / \mathrm{cm}^{3}$, as shown in Figure 2. The mechanical properties are measured in the laboratory (see Table 1 for the design parameters of the specimen).

The stress and strain curves of the closed-cell aluminum foam, with the dimensions of $100^{*} 100^{*} 50 \mathrm{~mm}$ and 


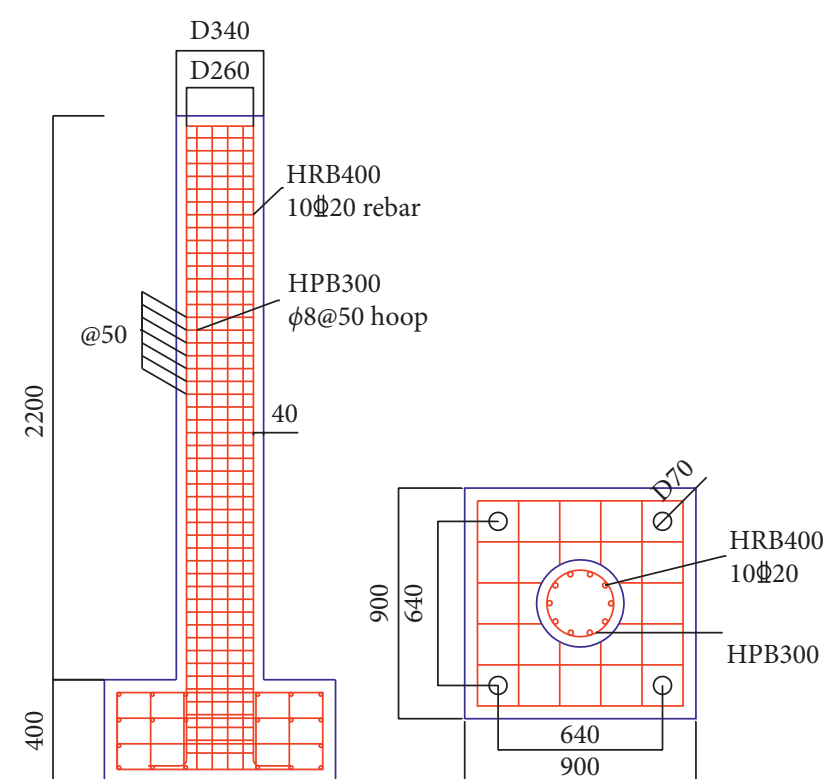

Figure 1: Schematic diagram of the specimen (dimension unit: $\mathrm{mm})$.

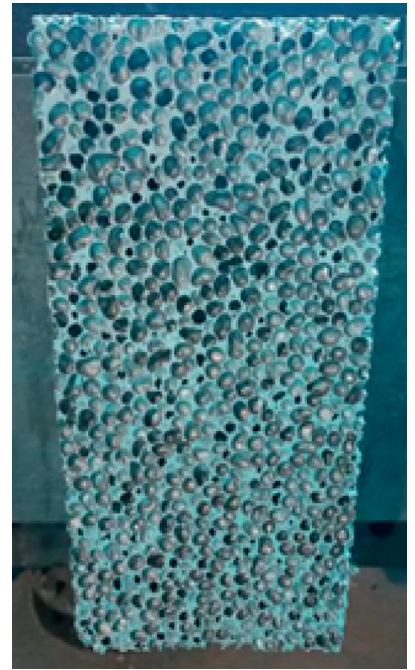

Figure 2: Closed-cell aluminum foam material.

$100 * 100 * 100 \mathrm{~mm}$, were obtained by the uniaxial compression test. The stress-strain curve of the closed-cell aluminum foam under the uniaxial compression test is shown in Figure 3.

From the stress-strain curve, we can determine the work done by deformation [30]:

$$
W=\int_{0}^{\varepsilon_{m}} \sigma d \varepsilon
$$

where $w$ represents the deformation work of closed-cell aluminum foam absorbed; $\sigma$ is the flow stress of closed-cell aluminum foam; and $\varepsilon_{m}$ is the flow strain of closed-cell aluminum foam.

$$
\sigma_{0}=\frac{\int_{\varepsilon_{a}}^{\varepsilon_{b}} \sigma(\varepsilon) d \varepsilon}{\varepsilon_{b}-\varepsilon_{a}},
$$

where $\sigma_{0}$ is the strain of yield platform; $\varepsilon_{a}$ is the yield strain; and $\varepsilon_{b}$ is the densification strain.

The material parameters of the closed-cell aluminum foam are calculated using formulae (1) and (2), as shown in Table 2.

And 12 cubes $(150 \mathrm{~mm} \times 150 \mathrm{~mm} \times 150 \mathrm{~mm})$ were made to carry out the compressive test; the compressive test was carried out on the universal electrohydraulic servo testing machine to obtain the yield strength and ultimate strength of the reinforcement. The mechanical properties of the concrete are shown in Table 3.

In the test, the steel bars in the specimen were tensioned to obtain the yield strength, ultimate strength and bearing capacity of the stainless steel bars and ordinary steel bars. The stress with the residual strain of the stainless steel bars of $0.2 \%$ was the yield strength, the details of which are shown in Table 4. Table 5 shows a comparison of the strength replacement of the pier specimens.

2.2. Data Collection. The test mainly collects the data of impact force, specimen displacement, strain of reinforcement, crack development of specimen, and concrete damage. Among these, the impact force is measured by the pressure sensor at the head of the trolley, the dynamic strain of reinforcement is measured by the strain gauge, and a total of eight strain gauges of reinforcement are arranged according to the stress characteristics of the specimen, with their distribution as shown in Figure 4. In addition, four displacement meters (as shown in Figure 5) are arranged at the locations of $100 \mathrm{~mm}, 800 \mathrm{~mm}$, $1,500 \mathrm{~mm}$, and $2,100 \mathrm{~mm}$ from top to bottom on the back of the specimen so as to collect the data of lateral displacement of bridge column. Finally, an HC-U81 concrete ultrasonic detector is used to detect the main failure area of the specimens.

2.3. Test Device and Design. The test is completed on a multifunctional ultrahigh heavy drop hammer testing machine, as shown in Figure 6. The multifunctional ultrahigh heavy drop hammer testing machine is mainly composed of a trolley, a vertical drop hammer, and a steel wire rope. The kinetic energy of the trolley is provided by adjusting the height of the vertical drop hammer (as shown in Figure 7). Among them, the maximum lifting height of drop hammer is $18 \mathrm{~m}$, the change range of drop hammer is $166-1,500 \mathrm{~kg}$, and the mass of the trolley is $1,200 \mathrm{~kg}$ which can also be changed through the counterweight mass block. In this test, the counterweight of the drop hammer is $196 \mathrm{~kg}$ and that of the trolley is $1,200 \mathrm{~kg}$.

According to the experimental design, each pier is impacted six times, and the impact scheme is shown in Table 6.

Before the impact, the upper end of the column is applied with an axial pressure of $250 \mathrm{kN}$, in order to limit the horizontal displacement of the column (as shown in 
TABLE 1: Design parameters of specimen for test.

\begin{tabular}{|c|c|c|c|c|c|}
\hline Group & Specimen no. & Longitudinal reinforcement (mm) & Stirrup $(\mathrm{mm})$ & Concrete strength grade & $\begin{array}{l}\text { Aluminum foam no. used for } \\
\text { specimen }\end{array}$ \\
\hline \multirow{2}{*}{-} & S1-16 & $10 S 16$ & Ф8@50 & $\mathrm{C} 40$ & A1 \\
\hline & $\mathrm{Z} 2-20$ & $10 \Phi 20$ & Ф8@50 & $\mathrm{C} 40$ & A1 \\
\hline \multirow{2}{*}{-} & S1-20 & $10 S 20$ & Ф8@50 & $\mathrm{C} 40$ & A2 \\
\hline & $\mathrm{Z} 2-25$ & $10 \Phi 25$ & Ф8@50 & $\mathrm{C} 40$ & A2 \\
\hline
\end{tabular}

Note. S represents the stainless steel reinforcement (S2304).

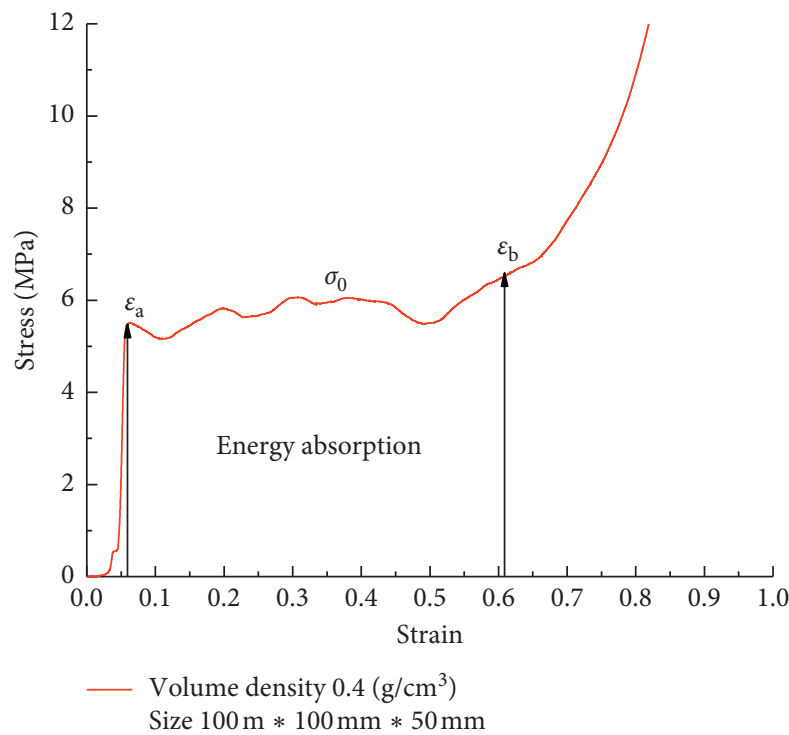

(a)

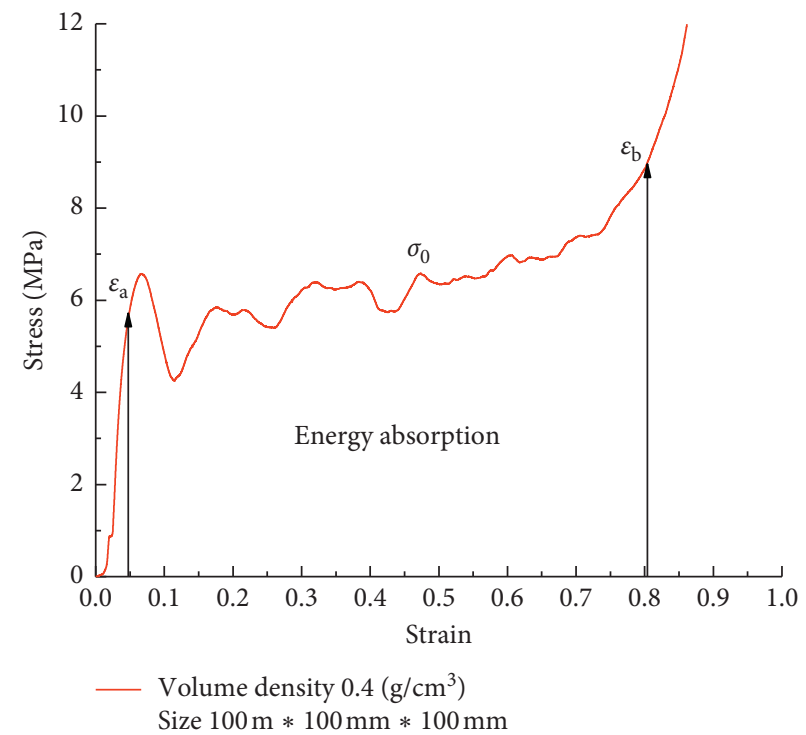

(b)

FIgURE 3: Stress-strain curves of closed-cell aluminum foam under the uniaxial compression test.

TABle 2: Parameters of closed-cell aluminum foam material.

\begin{tabular}{lccccc}
\hline Material no. & Volume density $\left(\mathrm{g} / \mathrm{cm}^{3}\right)$ & Thickness $(\mathrm{mm})$ & Porosity $(\%)$ & Compressive strength $\left(\mathrm{N} / \mathrm{mm}^{2}\right)$ & Tensile strength $\left(\mathrm{N} / \mathrm{mm}^{2}\right)$ \\
\hline A1 & 0.4 & 85 & 5.7 & 3.0 & 3183 \\
A2 & 0.4 & 85 & 6.0 & 3.0 & 4880 \\
\hline
\end{tabular}

TABLe 3: Mechanical properties of the concrete.

\begin{tabular}{lcr}
\hline Concrete strength grade & Concrete strength $\left(\mathrm{N} / \mathrm{mm}^{2}\right)$ & Modulus of elasticity $\left(\mathrm{N} / \mathrm{mm}^{2}\right)$ \\
\hline C40 & 44.83 & $3.28 \times 10^{4}$ \\
\hline
\end{tabular}

TABle 4: Properties of the reinforcement materials.

\begin{tabular}{lcccc}
\hline Longitudinal reinforcement & Steel diameter $(\mathrm{mm})$ & Yield strength $\left(\mathrm{N} / \mathrm{mm}^{2}\right)$ & Ultimate strength $\left(\mathrm{N} / \mathrm{mm}^{2}\right)$ & Elasticity modulus $\left(\mathrm{N} / \mathrm{mm}^{2}\right)$ \\
\hline \multirow{2}{*}{ HPB400 } & 20 & 440 & 580 & $2.00 \times 10^{5}$ \\
\multirow{2}{*}{ S2304 } & 25 & 470 & 640 & 734 \\
& 16 & 670 & 858 & $1.93 \times 10^{5}$ \\
\hline
\end{tabular}

Figure 8). The base of the pier specimen is fixed to the foundation with four prestressed bolts, which can be approximately equivalent to a rigid section. After the specimen is placed, the closed-cell aluminum foam cushioning material is fixed on the rigid bow of the impact boat model (as shown in Figure 9). 
TABLE 5: Comparison of the equal-strength replacement of the pier specimens.

\begin{tabular}{|c|c|c|c|c|c|c|c|}
\hline Group & $\begin{array}{c}\text { Specimen } \\
\text { no. }\end{array}$ & $\begin{array}{l}\text { Bearing capacity of } \\
\text { single reinforcement } \\
(N)\end{array}$ & $\begin{array}{l}\text { Reinforcement } \\
\text { number }\end{array}$ & $\begin{array}{l}\text { Axial bearing } \\
\text { capacity of } \\
\text { member }(N)\end{array}$ & $\begin{array}{l}\text { Relative ratio of } \\
\text { axial bearing } \\
\text { capacity of } \\
\text { members }(\%)\end{array}$ & $\begin{array}{l}\text { Section bending } \\
\text { rigidity } \\
\left(\times 10^{12} \mathrm{~N} \mathrm{~mm}^{2}\right)\end{array}$ & $\begin{array}{l}\text { Relative ratio } \\
\text { of section } \\
\text { stiffness (\%) }\end{array}$ \\
\hline \multirow{2}{*}{ - } & S1-16 & 134643 & 10 & 5324885 & \multirow{2}{*}{0.31} & 26.57 & \multirow{2}{*}{-0.75} \\
\hline & $\mathrm{Z} 2-20$ & 138160 & 10 & 5308977 & & 26.77 & \\
\hline \multirow[b]{2}{*}{ - } & $\mathrm{S} 1-20$ & 224510 & 10 & 6188177 & \multirow{2}{*}{0.55} & 25.84 & \multirow{2}{*}{-4.57} \\
\hline & Z2-25 & 230593 & 10 & 6154133 & & 27.08 & \\
\hline
\end{tabular}

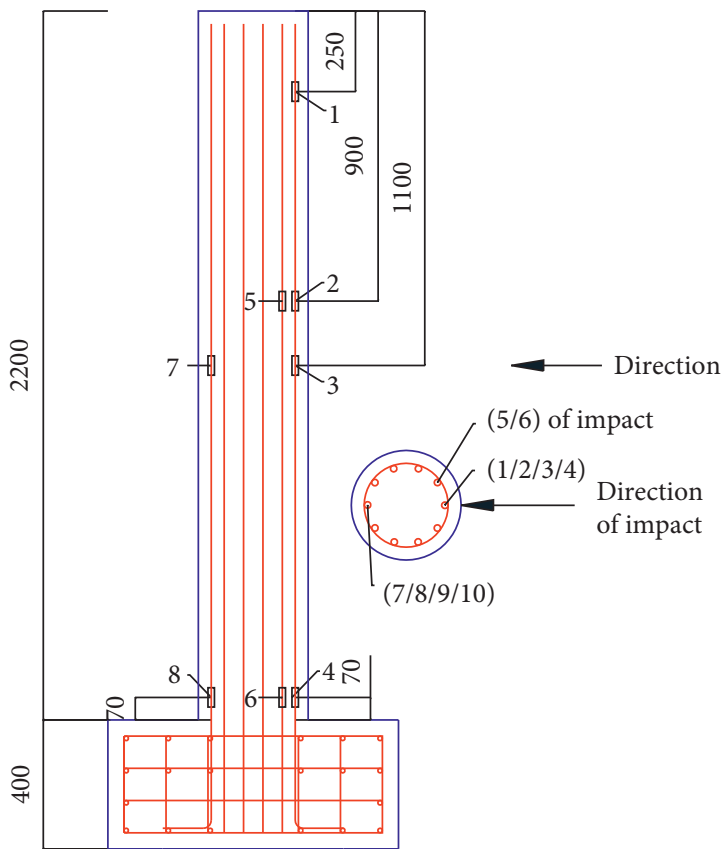

FIGURE 4: Diagram of reinforcement strain measurement points (unit: $\mathrm{mm}$ ).

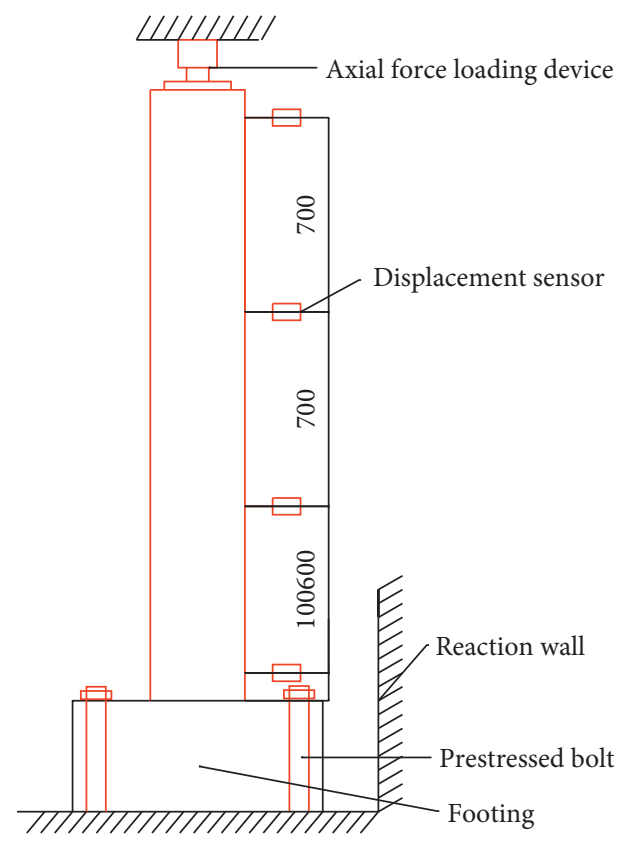

Figure 5: Diagram of displacement measurement points (unit: $\mathrm{mm})$.

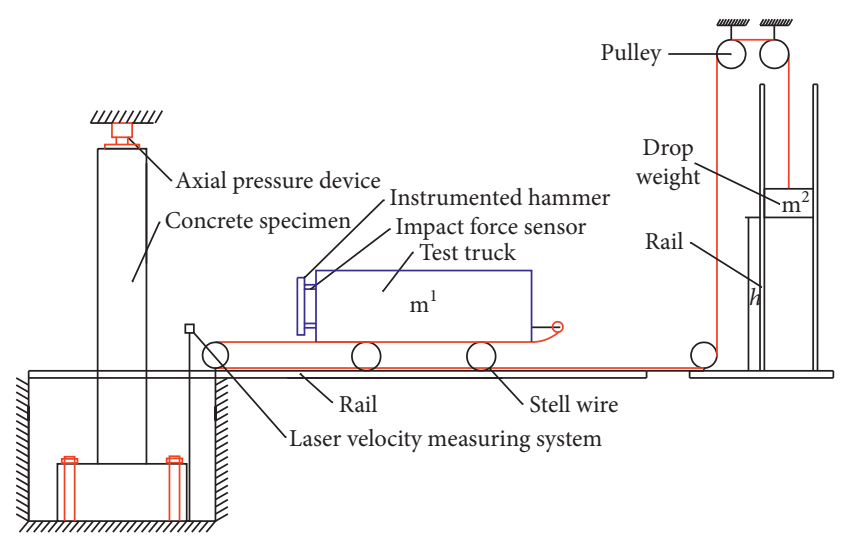

FIGURE 6: Multifunctional ultrahigh heavy drop hammer impact tester system.

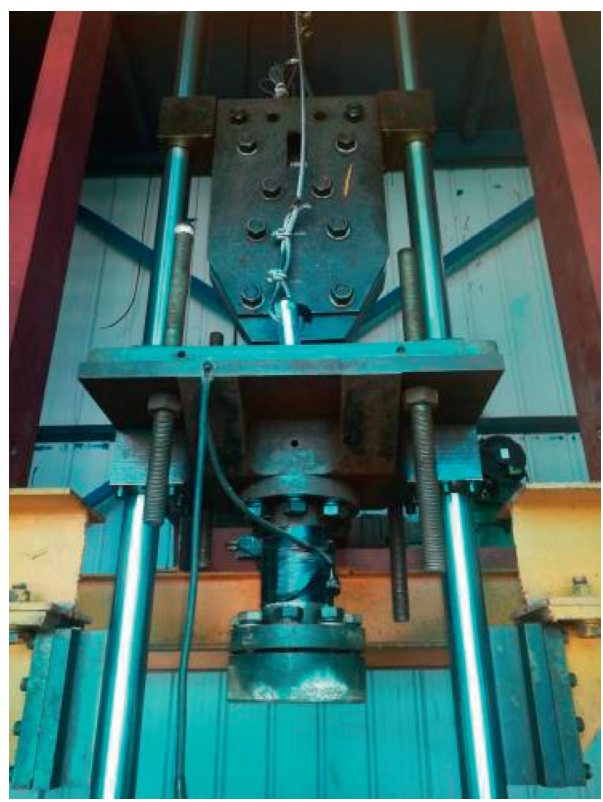

Figure 7: Vertical drop hammer.

\section{Test Result and Analysis}

Through the horizontal impact test, the dynamic response data of concrete piers after equal-strength replacement with stainless steel reinforcement can be obtained under different impact energies and under the protection of the closed-cell aluminum foam. These data mainly include the time history 
TABLE 6: Impact scheme.

\begin{tabular}{lccccc}
\hline Specimen no. Impact times & Height of the drop hammer $(\mathrm{m})$ & Average impact velocity (m/s) & $\begin{array}{c}\text { Accumulated } \\
\text { energy }(\mathrm{J})\end{array}$ & $\begin{array}{c}\text { Stress stage of closed-cell } \\
\text { aluminum foam }\end{array}$ \\
\hline S1-16 & 1 & 2 & 0.72 & 311.04 & \\
Z2-20 & 2 & 4 & 1.10 & 1037.04 & Yield stage \\
S1-20 & 3 & 6 & 1.42 & 2246.88 & \\
Z2-25 & 4 & 10 & 1.67 & 3920.22 & \\
& 5 & 12 & 1.84 & 5951.58 & Densification stage \\
\hline
\end{tabular}

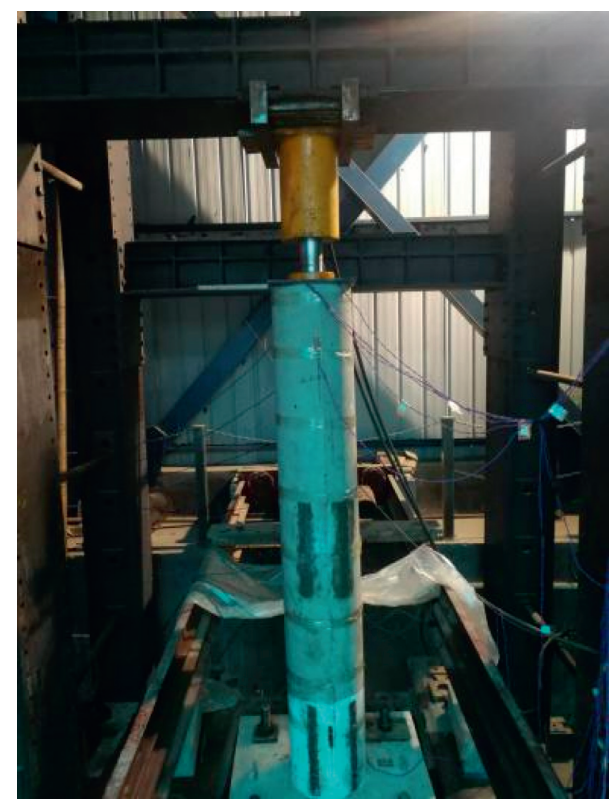

FIgURE 8: Impacted specimen and constraints.

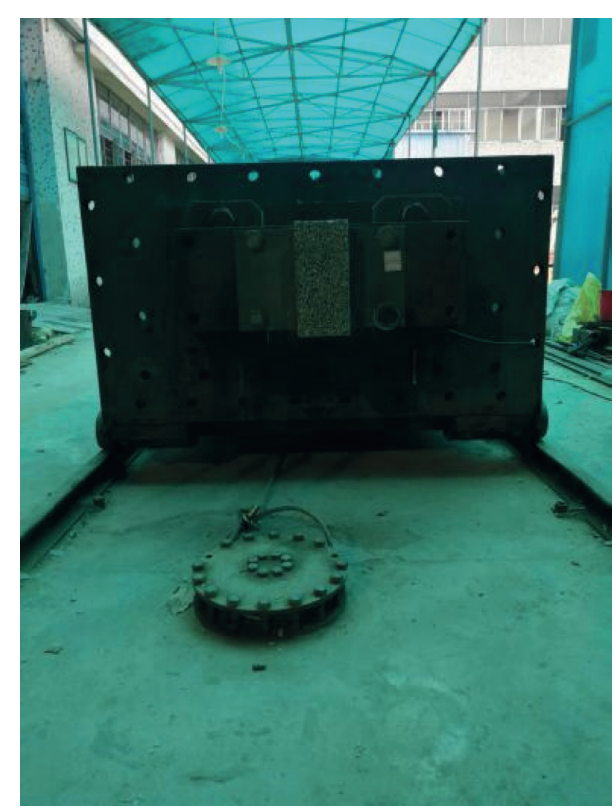

FIgURE 9: Horizontal traction impact test machine.

curve of impact force, time history curve of displacement, time history curve of strain of steel bar, damage of some parts of the specimen, and fracture propagation and failure mode. In order to better analyze the dynamic response of the two groups of specimens, the zero point of time is determined as the point when the trolley reaches the laser speed measurement system at the end of the track, namely, when the acquisition system is triggered.

3.1. Response Analysis of Impact Force. Under the condition of closed-cell aluminum foam, there is a significant difference in the ability to resist impact before and after the equalstrength replacement with stainless steel bars. Figure 10 shows the time history curves of impact force of the first group (S1-16 and Z2-20) and the second group (S1-20 and Z2-25) of specimens which are raised to $4 \mathrm{~m}$ and $10 \mathrm{~m}$, respectively. For specimens S1-16 (S for stainless steel) and $\mathrm{Z2}-20$, the $50 \mathrm{~mm}$ closed-cell aluminum foam is adopted, while for specimens S1-20 (S for stainless steel) and Z2-25, the $100 \mathrm{~mm}$ closed-cell aluminum foam is used.

It can be seen from Figure 10 that the change trend of the time history curve and peak value of impact force before and after the equal-strength replacement with stainless steel are consistent compared with that of ordinary reinforced concrete specimens. Throughout the impact process, the impact force rapidly reaches the peak value within $0.05 \mathrm{~s}$, and the peak duration is very short. At the same time, the peak value of the impact force is affected by the natural frequency of the component and overall stiffness of the component. The compression stress-strain curves of the closed-cell aluminum foam in Figure 3 show three stages: the linear elastic deformation stage, plastic platform stage, and densification stage. Finally, the peak impact test results of the two groups of piers are compared, and the results are shown in Table 7.

As shown in Table 7, the impact forces of specimens S116/S1-20 and Z2-20/Z2-25 gradually draw near to each other with the loss of the buffering effect of the aluminum foam under the same impact condition before and after the equalstrength replacement of stainless steel reinforcement. When the specimen is dominated by bending failure (such as in the first group), the impact force of S1-16 is greater than Z2-20. However, due to the fact that the ductility of ordinary reinforcement is greater than that of stainless steel and that stainless steel has high strength and toughness, the overall rigidity of the specimen is improved. In addition, when the specimen is dominated by shear failure (such as in the second group), the impact force of S1-20 is less than that of Z2-25. This occurs due to the fact that the shear failure is dominated by the staggered deformation of the concrete 


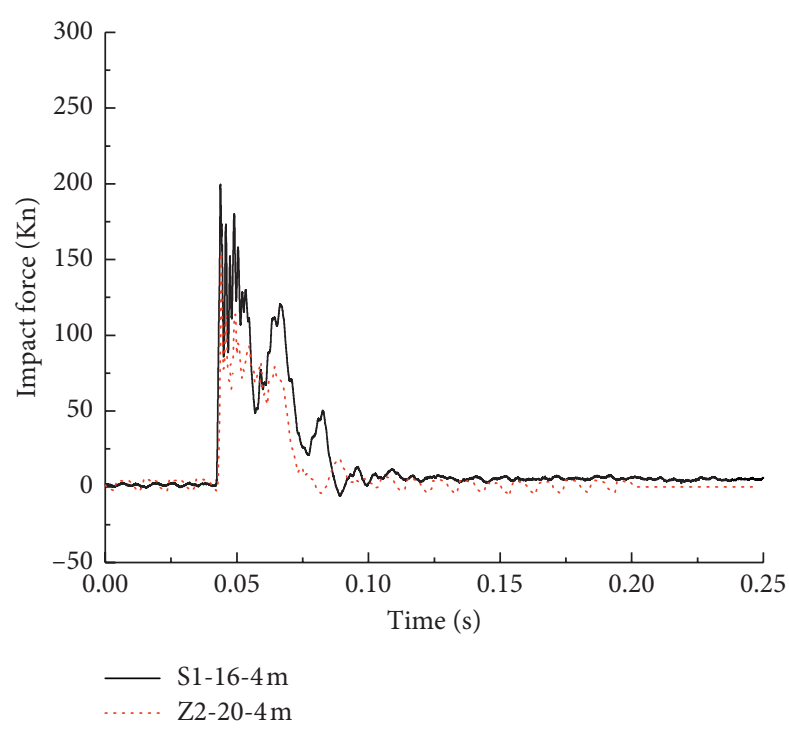

(a)

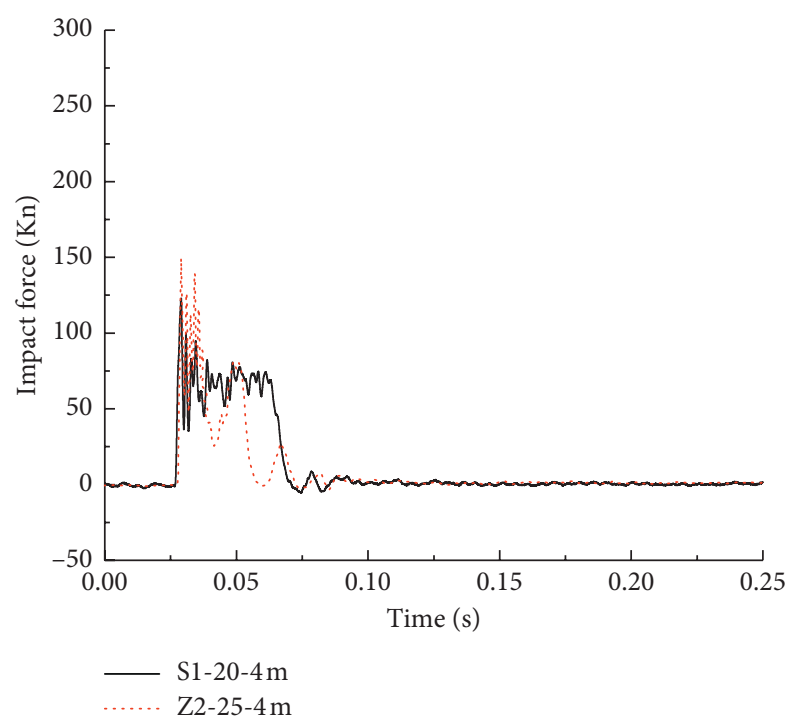

(c)

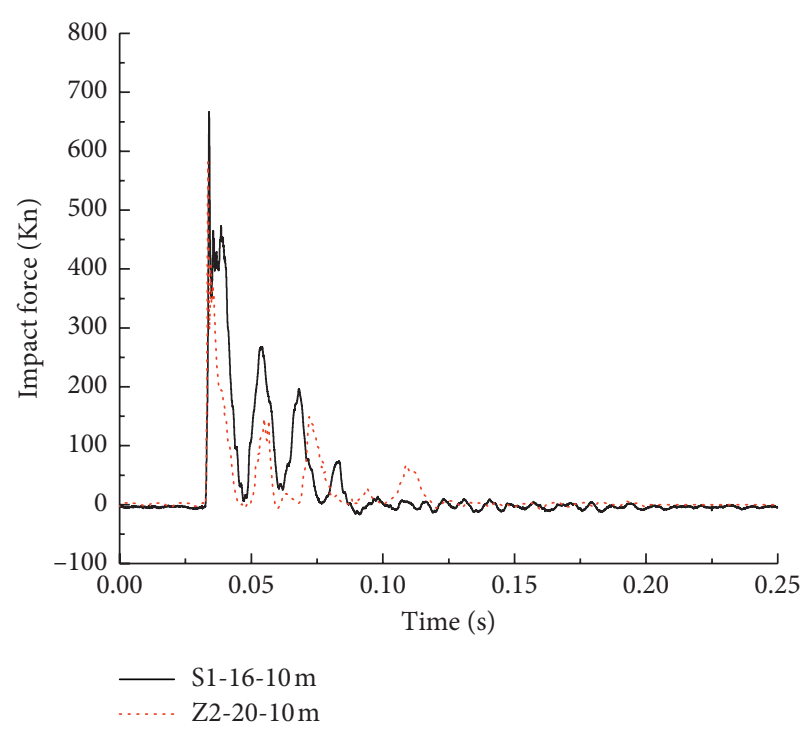

(b)

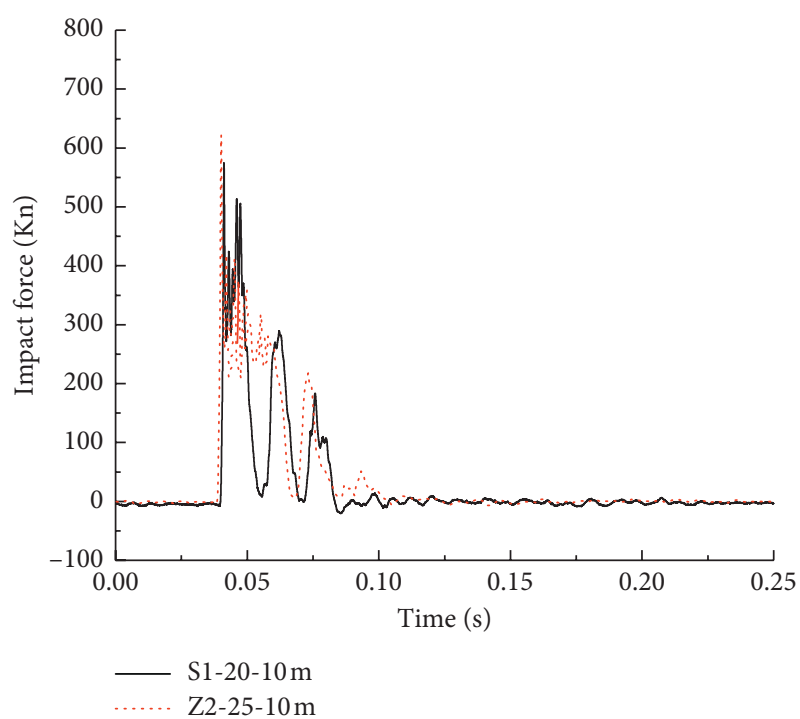

(d)

Figure 10: Time history curve of the impact force when the drop hammer is lifted to $4 \mathrm{~m}$ and $10 \mathrm{~m}$, respectively.

TABLE 7: Impact test results and comparison.

\begin{tabular}{|c|c|c|c|c|c|c|c|}
\hline \multirow{3}{*}{ Height of the drop hammer $(\mathrm{m})$} & \multirow{3}{*}{ Average impact velocity $(\mathrm{m} / \mathrm{s})$} & \multicolumn{3}{|c|}{$1^{\text {st }}$ group } & \multicolumn{3}{|c|}{$2^{\text {nd }}$ group } \\
\hline & & \multicolumn{2}{|c|}{$\begin{array}{l}\text { Peak impact } \\
\text { force }(\mathrm{kN})\end{array}$} & \multirow[t]{2}{*}{ Relative ratio (\%) } & \multicolumn{2}{|c|}{$\begin{array}{l}\text { Peak impact } \\
\text { force }(\mathrm{kN})\end{array}$} & \multirow[t]{2}{*}{ Relative ratio (\%) } \\
\hline & & S1-16 & $\mathrm{Z} 2-20$ & & S1-20 & $\mathrm{Z} 2-25$ & \\
\hline 2 & 0.72 & 111.57 & 85.91 & 23.00 & 89.3 & 115.2 & 22.48 \\
\hline 4 & 1.10 & 200.49 & 157.29 & 21.55 & 124.61 & 158.78 & 21.52 \\
\hline 6 & 1.42 & 313.66 & 208.15 & 33.64 & 153.47 & 188.43 & 18.55 \\
\hline 8 & 1.67 & 478.85 & 424.91 & 11.26 & 349.4 & 385.91 & 9.46 \\
\hline 10 & 1.84 & 672.11 & 607.87 & 9.56 & 578.77 & 635.43 & 8.92 \\
\hline 12 & 2.08 & 830.39 & 747.48 & 9.98 & 781.72 & 823.17 & 5.04 \\
\hline
\end{tabular}

section and that the cross section of the ordinary reinforced concrete pier has a slightly larger flexural rigidity than that of the stainless steel concrete pier. This indicates that the impact force is related to the overall stiffness as well as to the failure mode of the specimen. By comparing the peak impact force of two groups, the impact speed is fitted with the impact force, as shown by the peak impact force in the first and second groups in Figure 11. 


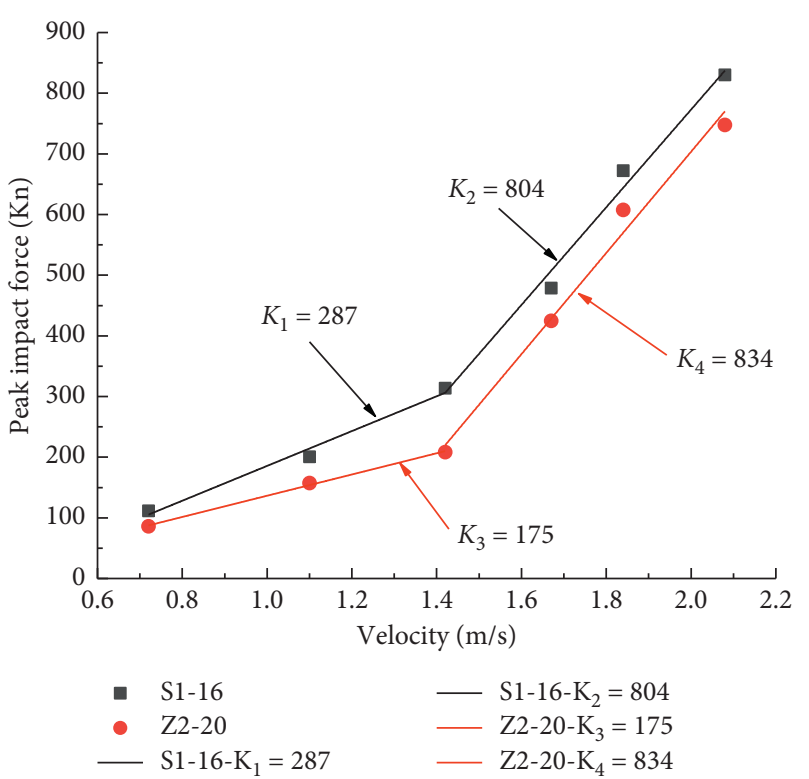

(a)

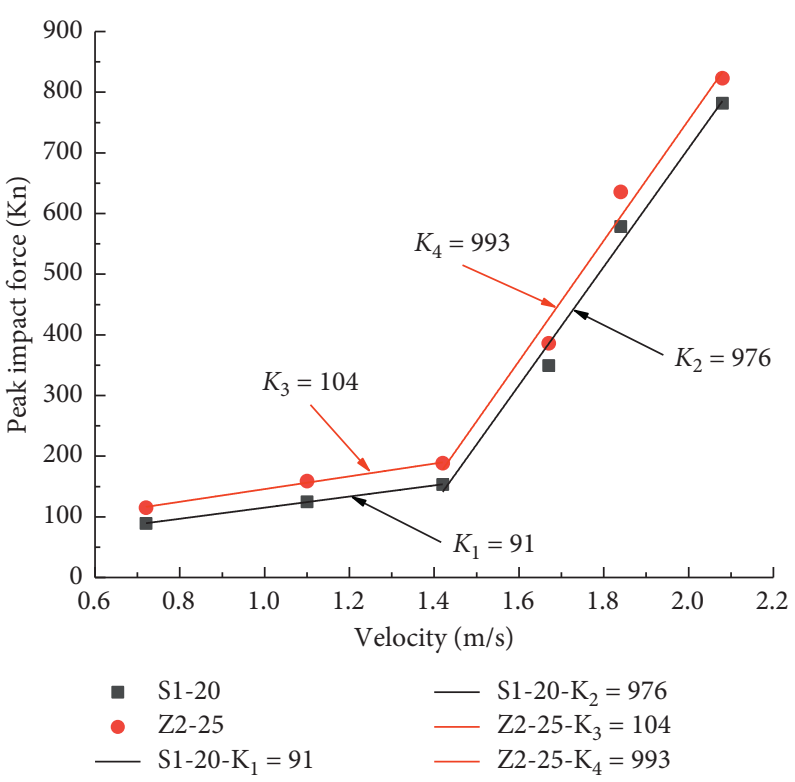

(b)

FIgURE 11: Peak impact force of the first and second groups.

It can be seen from Figure 11 and Table 5 that, overall, with the increase of impact speed, the change trend of impact force of the two groups of specimen remains approximately the same and presents a two-stage phenomenon. In the first stage, when the impact velocity is small (e.g., less than $1.42 \mathrm{~m} /$ s), the impact force of specimens S1-16/Z2-20 and S1-20/Z225 increases at a slope of 287, 175, 91, and 104, respectively, the rate of change is small, and the relative ratio of impact force is stable at $26 \%$ and $21 \%$, respectively. The main reason for this is that, at this time, the closed-cell aluminum foam is in an elastic stage and yielding stage and thus has a strong energy dissipation capability. In the second stage, when the impact velocity is high (e.g., greater than $1.67 \mathrm{~m} / \mathrm{s}$ ), the impact force of S1-16/Z2-20 and S1-20/Z2-25 increases linearly (from 287 to 804 , from 175 to 834 , from 91 to 976 , and from 104 to 993), with a large change rate, and the relative ratio of force is to better analyze the protective ability of closed cell aluminum foam cushioning material under the cumulative impact on the test specimen, not to describe the impact force (from $26 \%$ to $9 \%$ and from $21 \%$ to $7 \%$ ). This is due to the fact that the closed-cell aluminum foam has been transferred from the yield platform stage to the densification stage, as a result of the accumulation of impact energy, and the densification stage causes the stress to rapidly increase and the energy absorption to sharply decrease. This property is consistent with the stressstrain curve obtained from the uniaxial compression test of the closed-cell aluminum foam, as shown in Figure 3.

3.2. Displacement Time History Curve. Figure 12 shows the time history curve of the top displacement of the specimen in the first group (Z1-16/Z2-20) and second group (S1-20/Z2-25) when the drop hammer is lifted to $4 \mathrm{~m}$ and $10 \mathrm{~m}$, respectively.

Figures 12(a) and 12(c) show that the respective maximum displacement of the first group of specimens (Z2-20:
$4 \mathrm{~m}$ and S1-16: $4 \mathrm{~m}$ ) is $24.45 \mathrm{~mm}$ and $17.79 \mathrm{~mm}$ when the drop hammer is lifted to $4 \mathrm{~m}$, while that of the second group of specimens (Z2-25: $4 \mathrm{~m}$ and S1-20: $4 \mathrm{~m}$ ) is $20.39 \mathrm{~mm}$ and $13.15 \mathrm{~mm}$. It can be seen from Figures 12(b) and 12(d) that when the drop hammer is lifted to $10 \mathrm{~m}$, the maximum displacement of the first group of specimens (Z2-20: $10 \mathrm{~m}$ and S1-16: $10 \mathrm{~m}$ ) is $79.66 \mathrm{~mm}$ and $54.33 \mathrm{~mm}$ and that of the second group of specimens (Z2-25: $10 \mathrm{~m}$ and S1-20: $10 \mathrm{~m}$ ) is $58.95 \mathrm{~mm}$ and $46.49 \mathrm{~mm}$. From the above, we can see that under the condition of using closed-cell aluminum foam as the buffer layer, the impact displacement of the concrete piers after equal-strength replacement with stainless steel reinforcement is smaller than that of ordinary reinforced concrete piers. Finally, the peak displacement test data of the two groups of pier specimens are compared and analyzed, and the results are shown in Table 8.

Table 8 shows that the ability of members to resist impact deformation is improved under the same impact energy before and after equal-strength replacement with stainless steel. That is to say, under the same impact conditions, the displacement increment of the stainless steel reinforced concrete pier is smaller than that of the ordinary concrete pier, and the relative ratio of the displacement peak value is greater than $20 \%$, which is mainly due to the higher strength and toughness of stainless steel which improves the ability of members to resist the impact deformation. By comparing the top peak displacement of the two groups, the impact velocity is fitted with the peak displacement at the top, as shown in Figure 13.

It can be seen from Figure 13 that, overall, with the increase of impact speed, the displacement change trend of the two groups of specimens is approximately the same and presents a two-stage phenomenon. In the first stage, when the impact velocity is less than $1.42 \mathrm{~m} / \mathrm{s}$, the top displacement of specimens S1-16/Z2-20 and S1-20/Z2-25 increases 


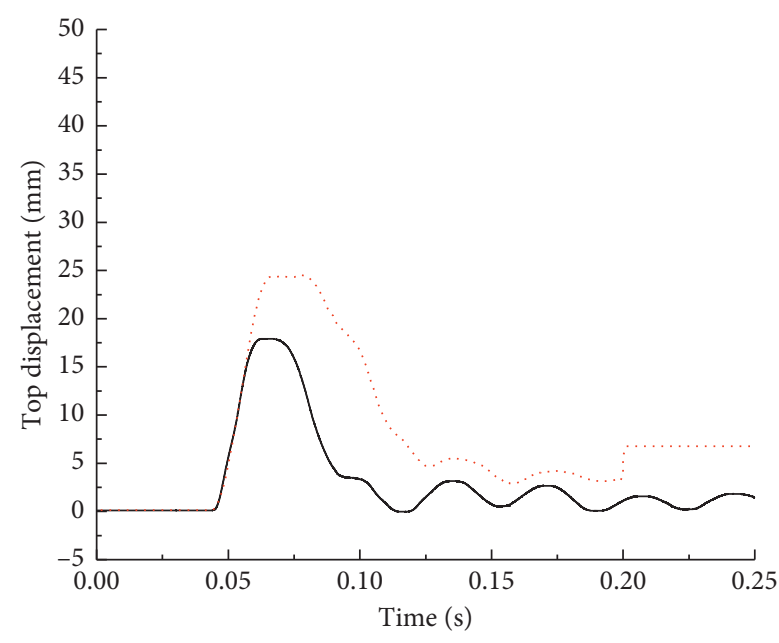

— S1-16-4m Z2-20-4m

(a)

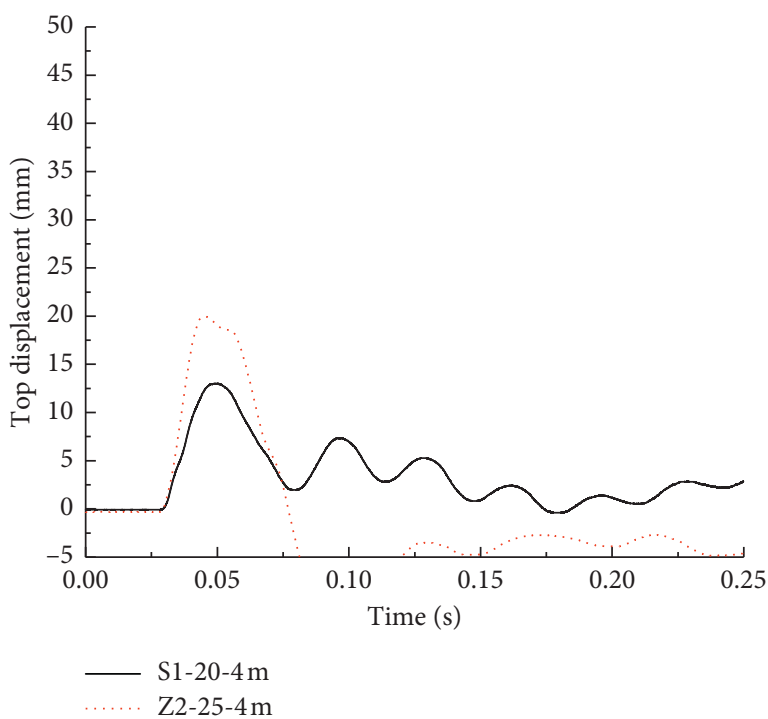

(c)

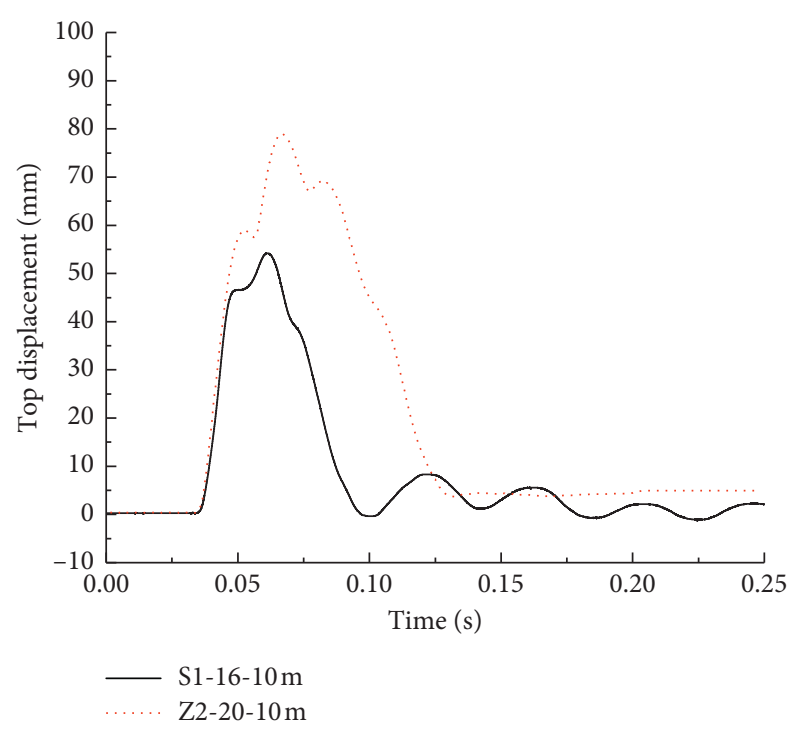

(b)

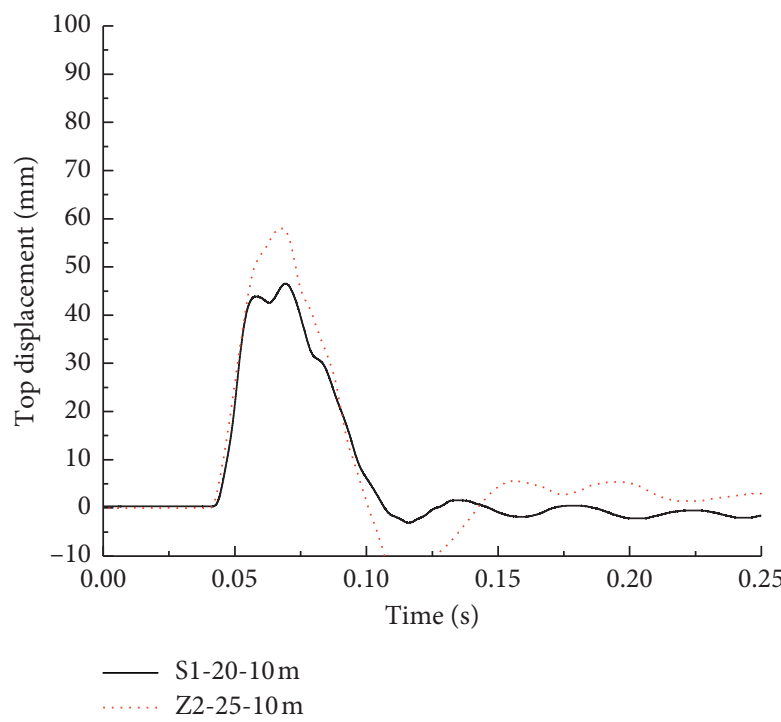

(d)

FIGURE 12: Time history curve of top displacement when the drop hammer is, respectively, lifted to $4 \mathrm{~m}$ and $10 \mathrm{~m}$.

TABLE 8: Top displacement test results and comparison.

\begin{tabular}{|c|c|c|c|c|c|c|c|}
\hline \multirow{3}{*}{$\begin{array}{l}\text { Height of the drop } \\
\text { hammer }(\mathrm{m})\end{array}$} & \multirow{3}{*}{$\begin{array}{l}\text { Average impact } \\
\text { velocity }(\mathrm{m} / \mathrm{s})\end{array}$} & \multicolumn{3}{|c|}{$1^{\text {st }}$ group } & \multicolumn{3}{|c|}{$2^{\text {nd }}$ group } \\
\hline & & \multicolumn{2}{|c|}{$\begin{array}{c}\text { Displacement } \\
\text { peak values }(\mathrm{mm})\end{array}$} & \multirow[t]{2}{*}{ Relative ratio (\%) } & \multicolumn{2}{|c|}{$\begin{array}{c}\text { Displacement } \\
\text { peak values }(\mathrm{mm})\end{array}$} & \multirow[t]{2}{*}{ Relative ratio (\%) } \\
\hline & & S1-16 & $\mathrm{Z} 2-20$ & & $\mathrm{~S} 1-20$ & $\mathrm{Z} 2-25$ & \\
\hline 2 & 0.72 & 10.19 & 14.96 & 31.89 & 10.98 & 14.55 & 24.54 \\
\hline 4 & 1.10 & 17.79 & 24.45 & 27.24 & 13.15 & 20.39 & 35.51 \\
\hline 6 & 1.42 & 32.11 & 41.71 & 27.81 & 20.75 & 31.48 & 34.09 \\
\hline 8 & 1.67 & 41.76 & 60.94 & 31.47 & 32.1 & 42.37 & 24.24 \\
\hline 10 & 1.84 & 54.33 & 79.66 & 31.80 & 46.49 & 58.95 & 21.14 \\
\hline 12 & 2.08 & 70.13 & 90.39 & 22.41 & 57.55 & 75.1 & 23.37 \\
\hline
\end{tabular}




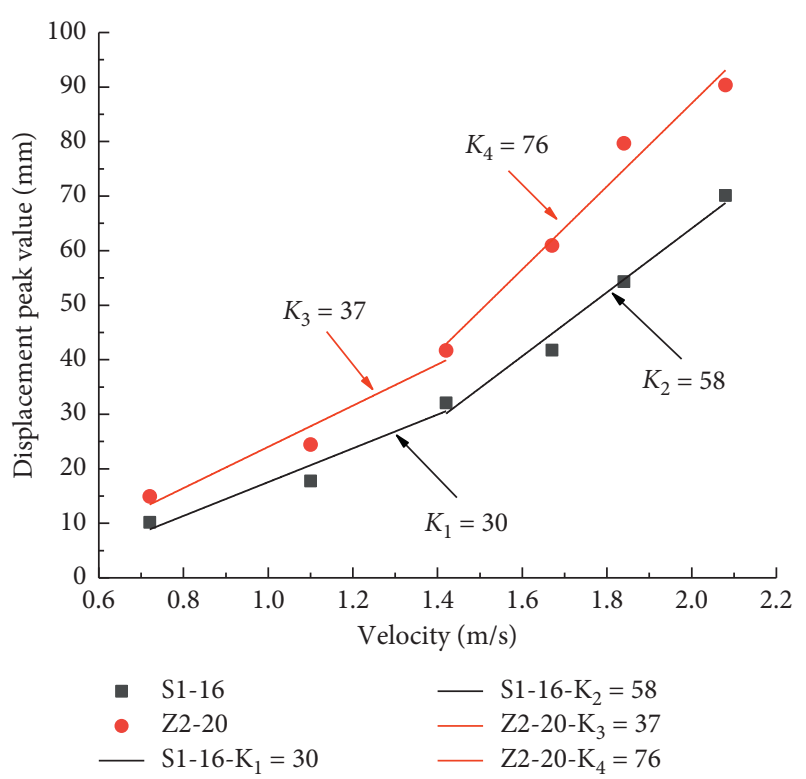

(a)

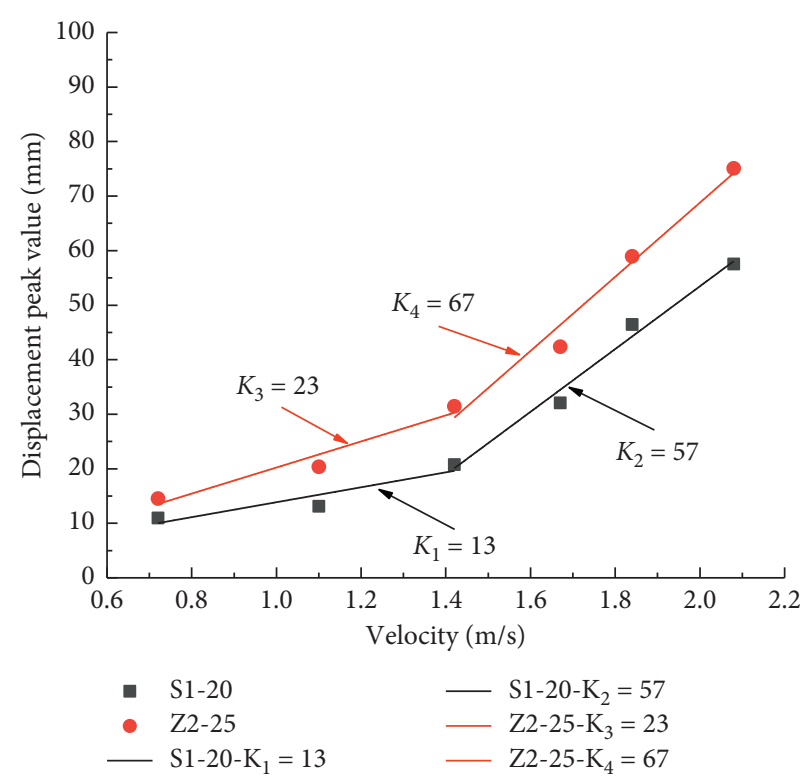

(b)

Figure 13: Top peak displacement of the first and second groups.

slowly and shows a linear increase at the slopes of 30, 37, 13, and 23, and its change rate is small. This is mainly due to the fact that the closed-cell aluminum foam is in the elastic or yielding stage and thus can absorb the impact energy more effectively. In the second stage, when the impact velocity is greater than $1.42 \mathrm{~m} / \mathrm{s}$, the top displacement of specimens S116/Z2-20 and S1-20/Z2-25 increases rapidly and shows a linear increase (from 30 to 58 , from 37 to 76 , from 13 to 57 , and from 23 to 67 ), and the change rate is larger. The main reason for this is that with the increase of impact energy, the closed-cell aluminum foam reaches the densification stage and gradually loses its cushioning ability, while the stiffness of the closed-cell aluminum foam increases after compaction and densification. This in turn leads to an increase in the structural impact response acceleration and displacement so that the dynamic response of bridge pier is increased in the densification stage. Therefore, when the closed-cell aluminum foam is used as the cushion material of the pier, the foam aluminum must eventually be replaced.

\subsection{Time History Curve of Concrete Damage Strain Detection.} Figure 14 shows the peak strain change curve of the \#4 steel bar at the lower part of the front of the impact point when the first group (S1-16/Z2-20) and second group (S1-20/Z225) of drop hammers are lifted to $4 \mathrm{~m}$ and $10 \mathrm{~m}$.

It can be seen from Figure 14 that the strain time history curve and peak change trend of the equal-strength replacement specimen are basically the same. Under the same impact energy, the strain changes of the ordinary reinforced concrete specimen and stainless steel specimen are almost the same. From the perspective of the strain of the reinforcement, the stainless steel reinforcement can be used to replace the ordinary reinforcement in the pier. Next, from the stress-strain formula $(\sigma=\varepsilon \times E)$, the stress value of the reinforcement is obtained. Finally, the stress values of the different yield strengths of reinforcement are compared (Table 4), and the peak strain and stress of two groups of \#4 reinforcement shown in Table 9 are obtained.

According to the strain value of reinforcement shown in Table 9, it is observed that the peak strain of reinforcement of each specimen also increases with the increase of impact height. Under the conditions of closed-cell aluminum foam protection, the peak value of reinforcement strain of specimens S1-16 and S1-20 is smaller than that of Z2-20 and Z225 before and after the equal-strength replacement with stainless steel. This is mainly due to the fact that the high strength and plasticity of stainless steel bars improve the impact resistance of the piers and reduce the ductility of the piers. The densification of closed-cell aluminum foam has a certain effect on the strain of reinforcement at the first group of measuring points, yet the influence on the strain of reinforcement at the second group of measuring points is not significant, which is mainly caused by the different impact resistances and impact failure modes of the component. According to the peak strain of the two groups of \#4 reinforcement shown in Table 9, the stress value of reinforcement is obtained from the strain, and the relationship between the stress of reinforcement and impact velocity is as shown in Figure 15.

It can be seen from Figure 15 that, under the impact load, the steel stress shows different results due to different failure modes of the two groups before and after the equal-strength replacement with stainless steel. When the specimen is dominated by bending failure (such as in the first group), the stress of reinforcement gradually increases with the increase of impact speed. At this time, the ductility of reinforcement more accurately reflects the fact that it can consume a portion of the energy under impact load through reinforcement deformation, thereby resulting in the increase of 


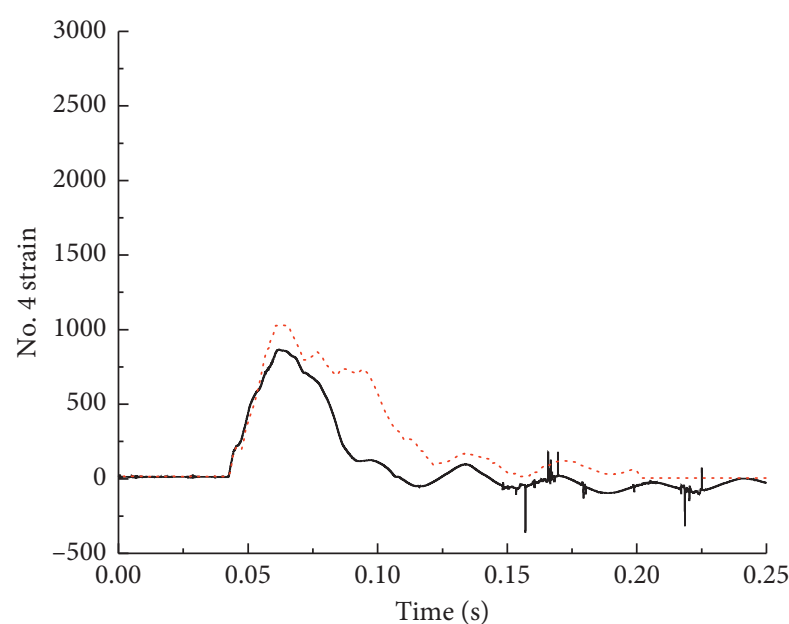

S $1-16-4 \mathrm{~m}$

(a)

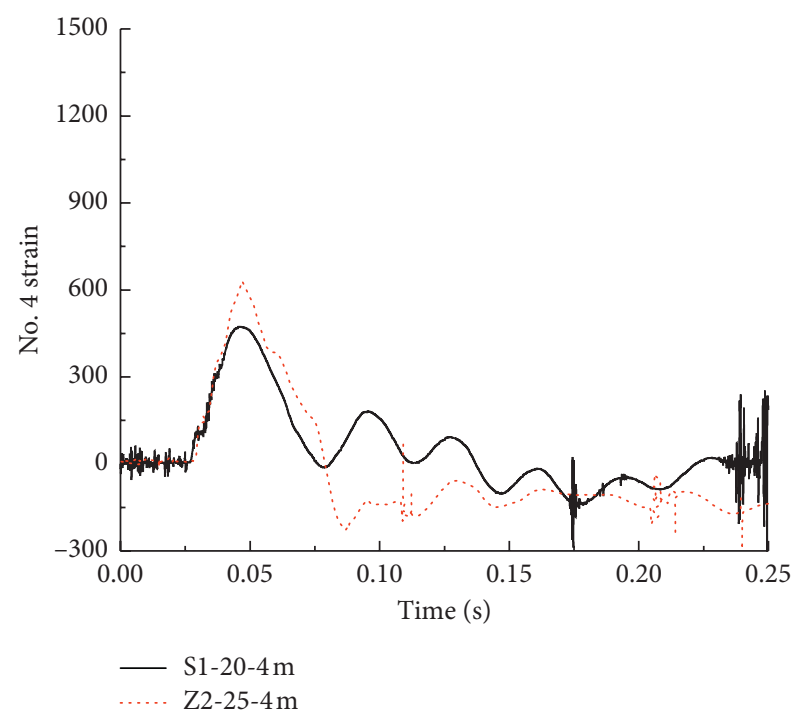

(c)

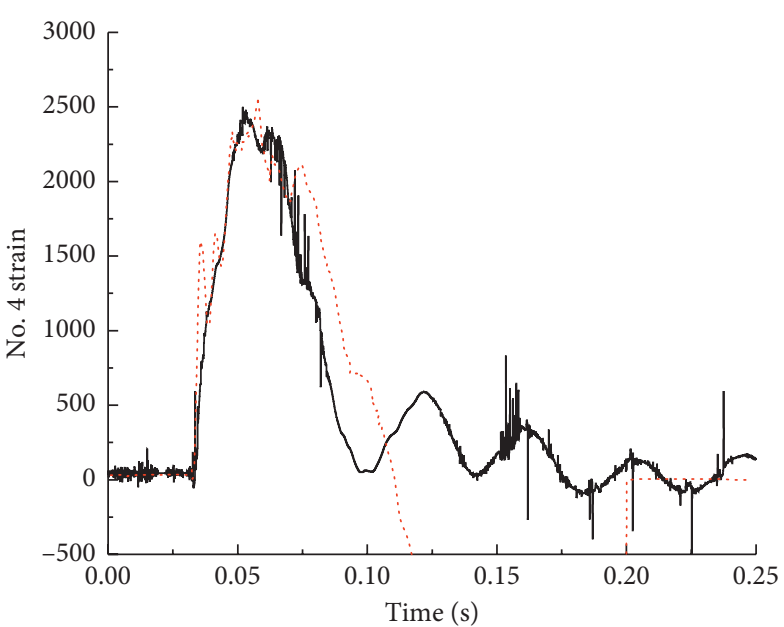

- S1-16-10m Z2-20-10m

(b)

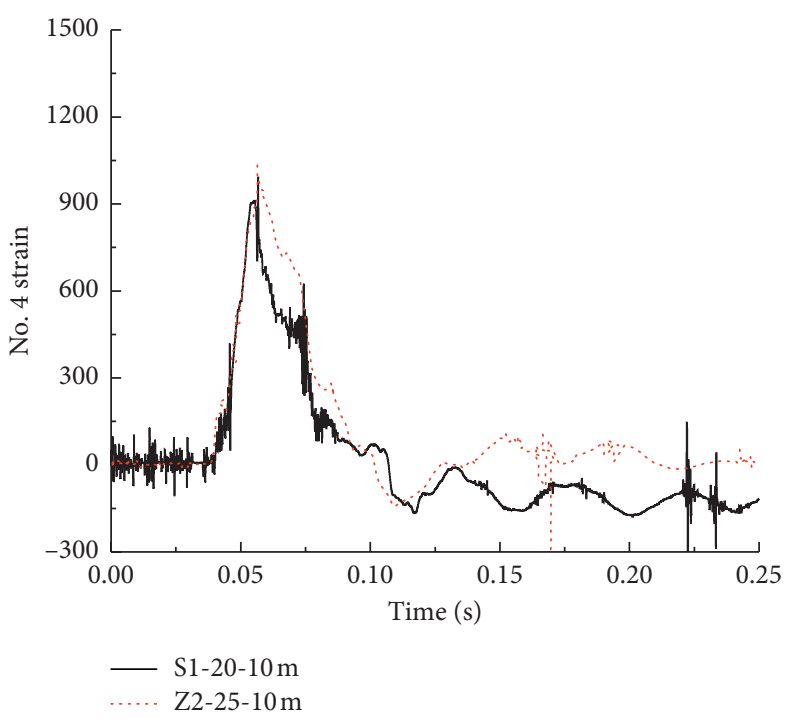

(d)

FIgURE 14: Time history curve of strain of the \#4 steel bar when the drop hammer is lifted to $4 \mathrm{~m}$ and $10 \mathrm{~m}$.

TABLE 9: Peak strain and stress test results of \#4 reinforcement.

\begin{tabular}{|c|c|c|c|c|c|c|c|c|c|}
\hline \multirow{3}{*}{ Height of drop hammer $(\mathrm{m})$} & \multirow{3}{*}{ Average impact velocity $(\mathrm{m} / \mathrm{s})$} & \multicolumn{4}{|c|}{$1^{\text {st }}$ group } & \multicolumn{4}{|c|}{$2^{\text {nd }}$ group } \\
\hline & & \multicolumn{2}{|c|}{ No. 4 peak $(\mu \varepsilon)$} & \multicolumn{2}{|c|}{$\begin{array}{l}\text { No. } 4 \text { stress } \\
(\mathrm{MPa})\end{array}$} & \multicolumn{2}{|c|}{ No. 4 peak $(\mu \varepsilon)$} & \multicolumn{2}{|c|}{$\begin{array}{l}\text { No. } 4 \text { stress } \\
(\mathrm{MPa})\end{array}$} \\
\hline & & S1-16 & $\mathrm{Z} 2-20$ & S1-16 & $\mathrm{Z} 2-20$ & $\mathrm{~S} 1-20$ & $\mathrm{Z} 2-25$ & S1-20 & $\mathrm{Z} 2-25$ \\
\hline 2 & 0.72 & 543.38 & 694.88 & 104.87 & 138.98 & 203.14 & 355.09 & 39.21 & 71.02 \\
\hline 4 & 1.10 & 864.53 & 1050.23 & 166.85 & 210.05 & 460.43 & 634.13 & 78.28 & 126.83 \\
\hline 6 & 1.42 & 1564.35 & 1573.97 & 325.08 & 314.79 & 550.25 & 809.56 & 106.20 & 161.91 \\
\hline 8 & 1.67 & 2314.26 & 2387.23 & 465.95 & - & 652.21 & 872.95 & 125.88 & 174.59 \\
\hline 10 & 1.84 & 2543.88 & 2564.25 & 516.06 & - & 958.06 & 1004.32 & 184.91 & 200.86 \\
\hline 12 & 2.08 & 2812.34 & 2816.18 & 546.64 & - & 1011.43 & 1198.64 & 195.21 & 239.73 \\
\hline
\end{tabular}

stress of reinforcement. At the same time, when the specimen is dominated by shear failure (such as in the second group), the stress of reinforcement tends to be flat with the increase of impact speed. The shear failure is dominated by the staggered deformation of concrete section, and there is less energy available for consuming the impact load through the reinforcement deformation, thereby resulting in the slow growth of the stress of the reinforcement. This shows that, 


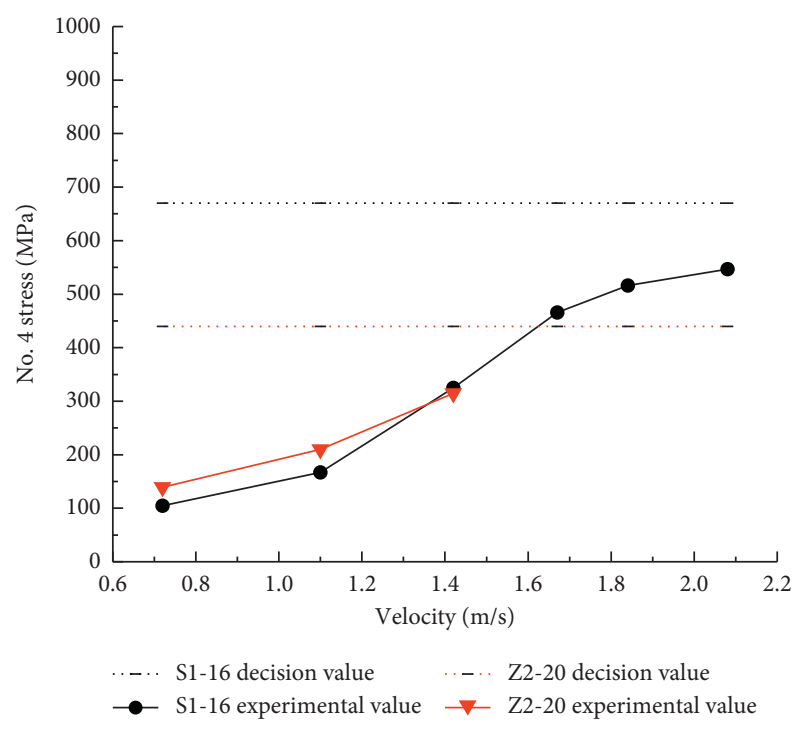

(a)

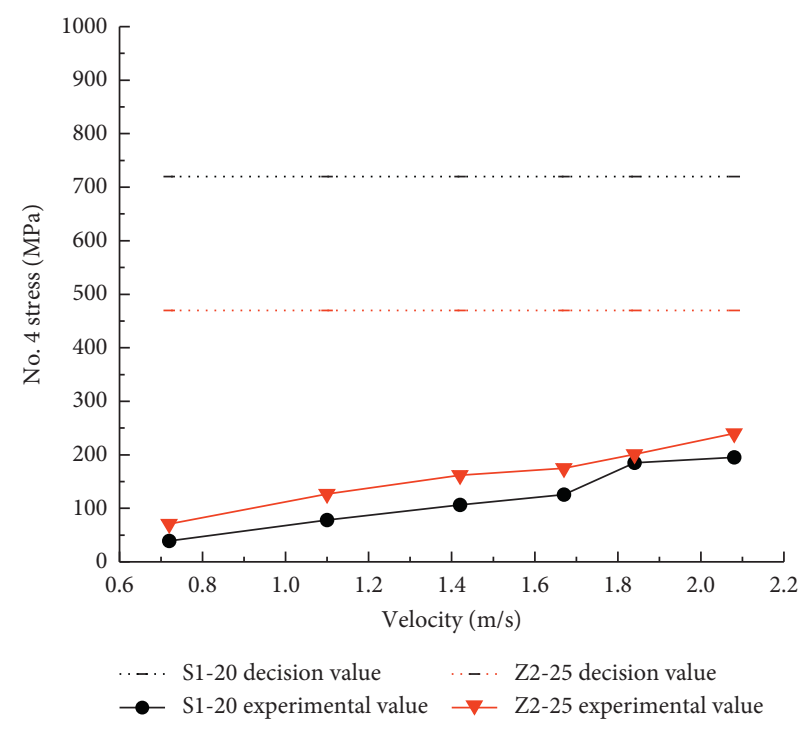

(b)

FIGURE 15: Fitting of stress and impact velocity of \#4 reinforcement. Note: the reinforcement reaches yield when Z2-20 is $1.42 \mathrm{~m} / \mathrm{s}$, at which point its elastic modulus cannot be determined, and thus only the first three values are taken.

under different failure modes, the bearing capacity of the reinforcement of the component differs in terms of resisting the impact deformation.

3.4. Concrete Damage Detection. Table 10 shows the changes of acoustic parameters recorded by an HC-U81 concrete ultrasonic loss meter after damage. After the concrete specimen is damaged, the transmission means of the ultrasonic wave will change, in turn leading to the increase of the transmission time of ultrasonic wave, i.e., a decrease in the sound speed.

It can be seen from Table 10 that the respective average change rates of ultrasonic sound speed of the first group of specimens (S1-16/Z2-20) are $-20.7 \%$ and $-22.17 \%$, while those of the second group (S1-20/Z2-25) are-15.16\% and $-17.54 \%$. From the perspective of damage, the change rate of sound velocity of concrete piers is similar before and after the equal-strength replacement with stainless steel bars. By fitting the ultrasonic sound speed reduction and impact speed measured by each specimen, the ultrasonic sound speed reduction and impact speed shown in Figure 16 can then be obtained.

It can be seen from Figure 16 and Table 10 that, overall, with the increase of impact speed, the change trend of concrete damage of the two groups of specimens is approximately the same and presents a two-stage phenomenon. In the first stage, when the impact velocity is less than $1.42 \mathrm{~m} / \mathrm{s}$, the respective sound velocity reductions of the first group of specimens (S1-16/Z2-20) are $-0.14 \mathrm{~km} / \mathrm{s}$ and $-0.152 \mathrm{~km} / \mathrm{s}$ and those of the second group (S1-20/Z2-25) are $-0.102 \mathrm{~km} / \mathrm{s}$ and $-0.127 \mathrm{~km} / \mathrm{s}$. By comparing the sound velocity reduction of the two groups, the sound velocity reduction is smaller, which is mainly a result of the superior energy-dissipating capacity of the closed-cell aluminum foam in the elastic and yielding stages. In the second stage, when the impact velocity is greater than $1.42 \mathrm{~m} / \mathrm{s}$, the first group of specimens (S1-16/Z2-20) has a sound speed reduction of $-0.755 \mathrm{~km} / \mathrm{s}$ and $-0.848 \mathrm{~km} / \mathrm{s}$, while the second group (S1-20/Z2-25) has a sound speed reduction of $-0.509 \mathrm{~km} / \mathrm{s}$ and $-0.606 \mathrm{~km} / \mathrm{s}$. Comparing the sound speed reduction of the two groups, we can see that the sound speed reduction is greater. This is mainly due to the fact that the closed-cell aluminum foam reaches the densification stage and gradually loses the buffer capacity with the increase of impact energy. On the contrary, this will increase the damage of the specimen, which can be verified by both impact force and displacement. Under the same impact speed, the change rate of sound speed of ordinary reinforced concrete specimens before and after impact is slightly larger than that of the stainless steel reinforced concrete specimens, which is mainly a result of the fact that stainless steel bars have greater strength and toughness compared with ordinary steel bars, so the stainless steel reinforced concrete piers show superior resistance to impact deformation. Figure 16(b) shows that when the impact velocity is not greater than $1.67 \mathrm{~m} / \mathrm{s}$, the reduction of ultrasonic velocity is relatively gentle, which is mainly because the thickness of the foam aluminum is $100 \mathrm{~mm}$. This indicates that the thickness of foam aluminum can delay its entry to the densification stage to a certain extent.

3.5. Crack Development and Failure Mode. Upon comparing the test results of the two groups of specimens, it is observed that when the impact height reaches a certain degree, large cracks appear at the bottom of the impact front area, while part of the concrete at the bottom of the impact back is crushed. In addition, at the impact point in the center of the affected frontal area, a small portion of the concrete is observed to be crushed, but the cracks are not obvious. Moreover, the crack development characteristics are very 
TABLe 10: Change of ultrasonic velocity of concrete.

\begin{tabular}{|c|c|c|c|c|c|c|c|c|}
\hline \multirow{2}{*}{ Specimen } & \multirow{2}{*}{$\begin{array}{l}\text { Height of } \\
\text { drop hammer } \\
(\mathrm{m})\end{array}$} & \multirow{2}{*}{$\begin{array}{c}\text { Average } \\
\text { impact } \\
\text { velocity }(\mathrm{m} / \mathrm{s})\end{array}$} & \multicolumn{2}{|c|}{$\begin{array}{l}\text { Average sound } \\
\text { velocity }(\mathrm{km} / \mathrm{s})\end{array}$} & \multirow{2}{*}{$\begin{array}{l}\text { Reduction of the } \\
\text { sound velocity } \\
(\mathrm{km} / \mathrm{s})\end{array}$} & \multirow{2}{*}{$\begin{array}{l}\text { Total reduction of } \\
\text { the sound velocity } \\
\qquad(\mathrm{km} / \mathrm{s})\end{array}$} & \multirow{2}{*}{$\begin{array}{l}\text { Change rate of } \\
\text { the sound } \\
\text { velocity }(\%)\end{array}$} & \multirow{2}{*}{$\begin{array}{c}\text { Specimen } \\
(\%)\end{array}$} \\
\hline & & & $\begin{array}{l}\text { Before } \\
\text { impact }\end{array}$ & $\begin{array}{c}\text { After } \\
\text { impact }\end{array}$ & & & & \\
\hline \multirow{6}{*}{ S1-16 } & 2 & 0.72 & 4.323 & 4.305 & 0.018 & & \multirow{6}{*}{-0.895} & \multirow{6}{*}{-20.7} \\
\hline & 4 & 1.10 & 4.305 & 4.256 & 0.049 & -0.14 & & \\
\hline & 6 & 1.42 & 4.256 & 4.183 & 0.073 & & & \\
\hline & 8 & 1.67 & 4.183 & 4.016 & 0.167 & & & \\
\hline & 10 & 1.84 & 4.016 & 3.739 & 0.277 & -0.755 & & \\
\hline & 12 & 2.08 & 3.739 & 3.428 & 0.311 & & & \\
\hline \multirow{6}{*}{$\mathrm{Z} 2-20$} & 2 & 0.72 & 4.51 & 4.491 & 0.019 & & \multirow{6}{*}{-1} & \multirow{6}{*}{-22.17} \\
\hline & 4 & 1.10 & 4.491 & 4.439 & 0.052 & -0.152 & & \\
\hline & 6 & 1.42 & 4.439 & 4.358 & 0.081 & & & \\
\hline & 8 & 1.67 & 4.358 & 4.181 & 0.177 & & & \\
\hline & 10 & 1.84 & 4.181 & 3.876 & 0.305 & -0.848 & & \\
\hline & 12 & 2.08 & 3.876 & 3.51 & 0.366 & & & \\
\hline \multirow{6}{*}{ S1-20 } & 2 & 0.72 & 4.031 & 4.018 & 0.013 & & \multirow{6}{*}{-0.611} & \multirow{6}{*}{-15.16} \\
\hline & 4 & 1.10 & 4.018 & 3.985 & 0.033 & -0.102 & & \\
\hline & 6 & 1.42 & 3.985 & 3.929 & 0.056 & & & \\
\hline & 8 & 1.67 & 3.929 & 3.849 & 0.08 & & & \\
\hline & 10 & 1.84 & 3.849 & 3.724 & 0.125 & -0.509 & & \\
\hline & 12 & 2.08 & 3.724 & 3.42 & 0.304 & & & \\
\hline \multirow{6}{*}{ Z2-25 } & 2 & 0.72 & 4.179 & 4.164 & 0.015 & & \multirow{6}{*}{-0.733} & \multirow{6}{*}{-17.54} \\
\hline & 4 & 1.10 & 4.164 & 4.119 & 0.045 & -0.127 & & \\
\hline & 6 & 1.42 & 4.119 & 4.052 & 0.067 & \multirow{4}{*}{-0.606} & & \\
\hline & 8 & 1.67 & 4.052 & 3.967 & 0.085 & & & \\
\hline & 10 & 1.84 & 3.967 & 3.824 & 0.143 & & & \\
\hline & 12 & 2.08 & 3.824 & 3.446 & 0.378 & & & \\
\hline
\end{tabular}

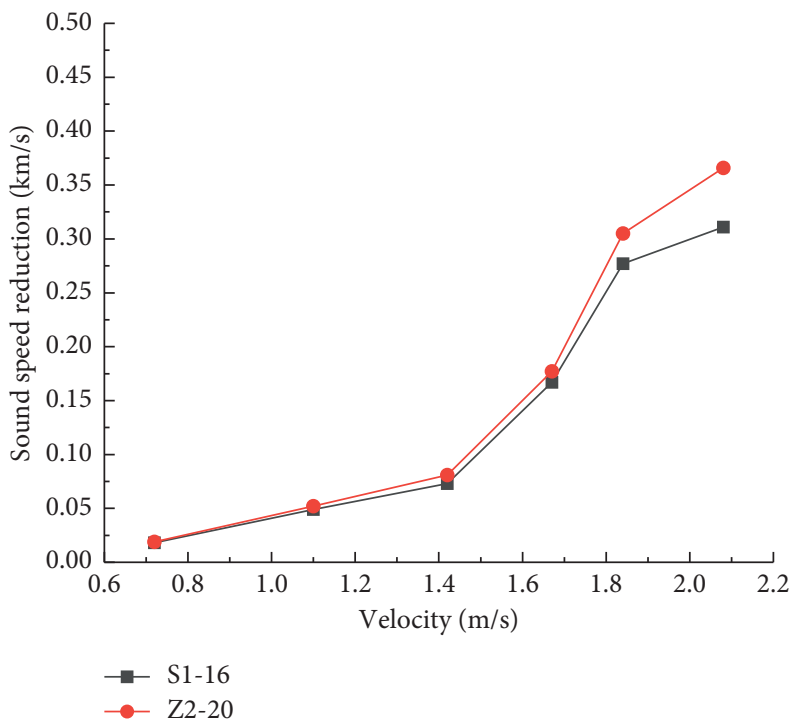

(a)

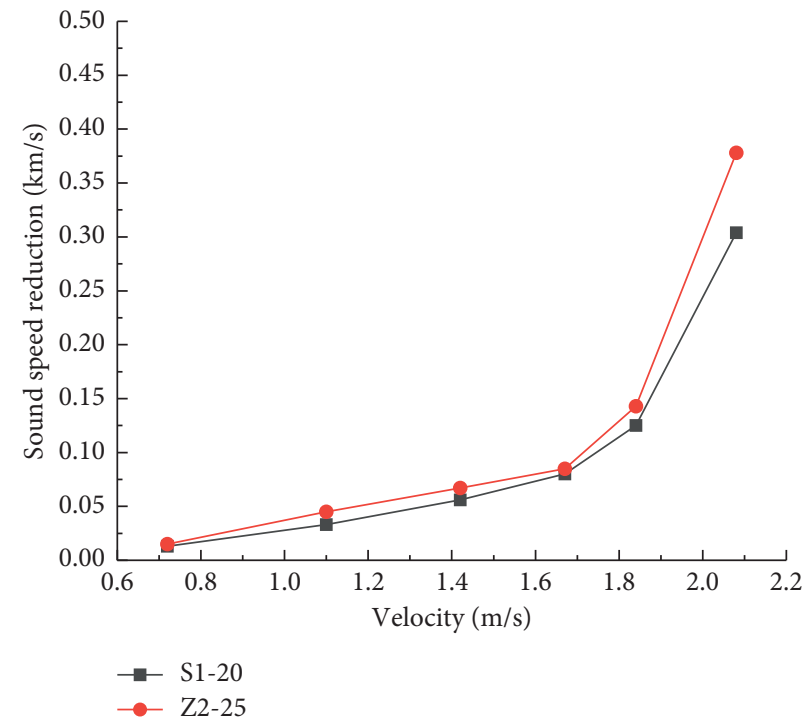

(b)

Figure 16: Correlation diagram between ultrasonic velocity reduction and impact velocity.

consistent with the main stress characteristics of the specimen. Table 11 shows the final crack development and failure of each specimen.

From Table 11, upon comparing the test results of stainless steel reinforced concrete specimens and ordinary reinforced concrete specimens, it is evident that the first group of specimens (S1-16/Z2-20) is dominated by bending failure, and the cracks of the specimens begin from the bottom area of the impact surface and then continue to derive and expand with the increase of impact energy. Under a certain level of impact energy, horizontal cracks appear near the impact surface and impact back area of the 
TABLE 11: Development and failure of the final crack of each specimen.
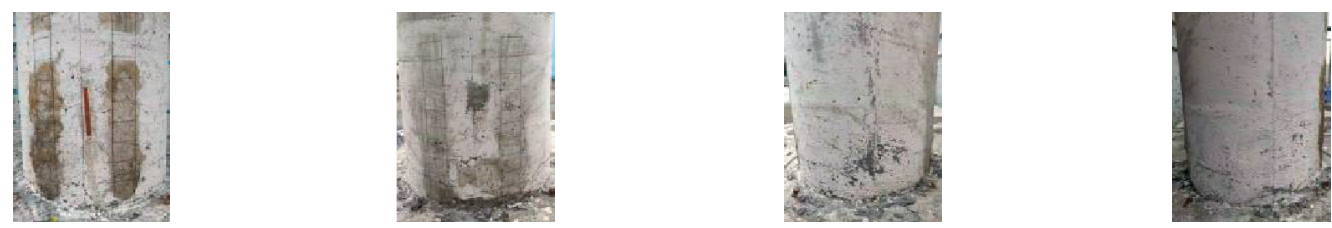

S1-16
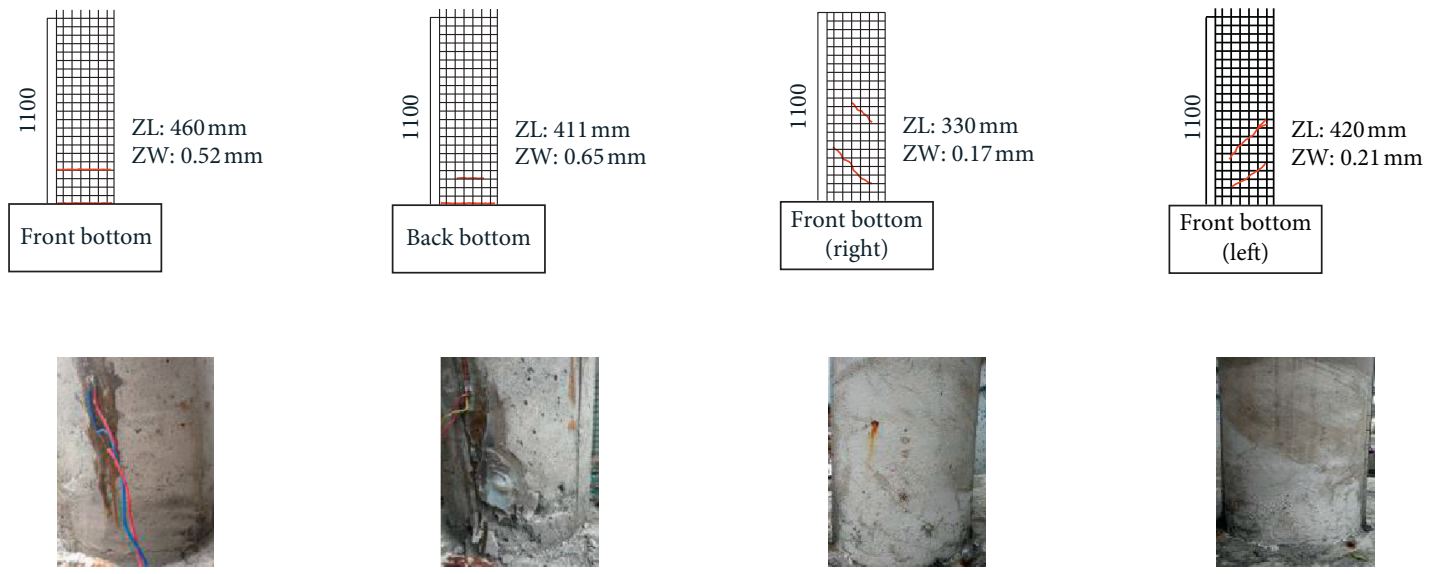

Z2-20
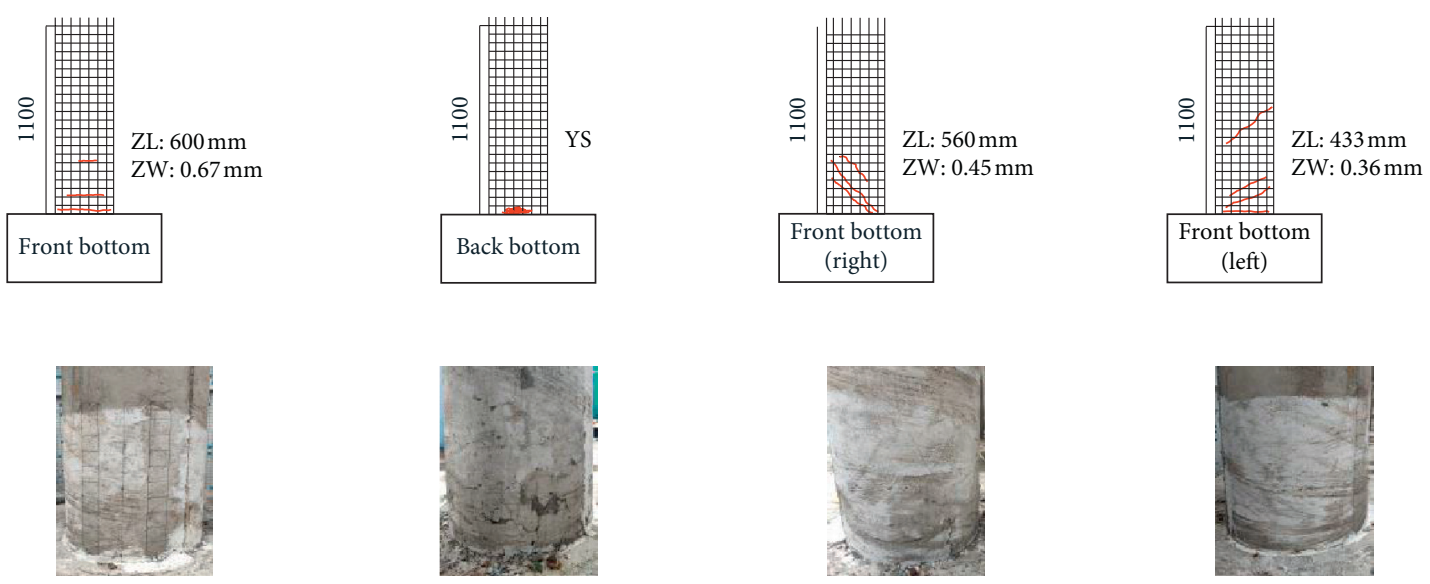

S1-20
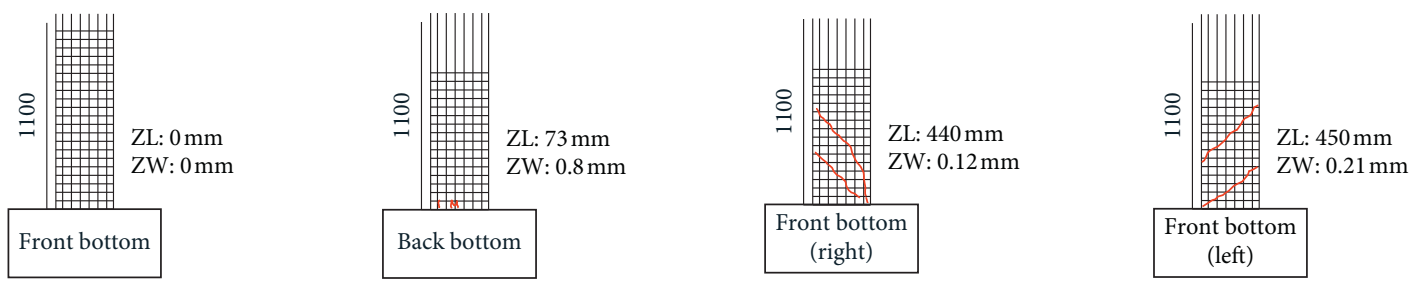
TABLe 11: Continued.

\begin{tabular}{lllll}
\hline Specimen no. & Front bottom & Back bottom & Front bottom (right) & Front bottom (left)
\end{tabular}
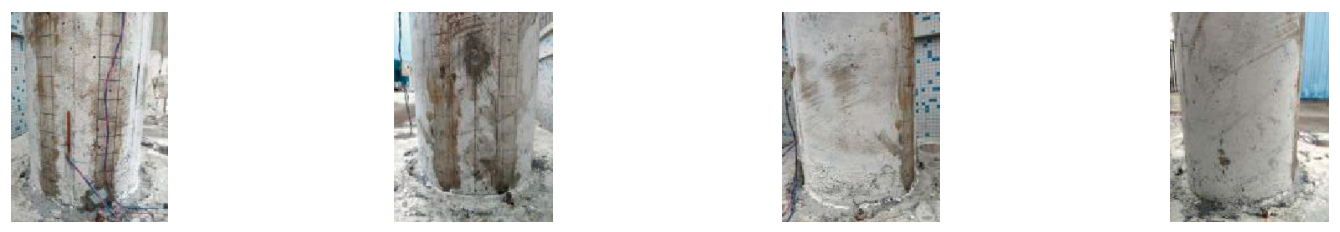

$\mathrm{Z} 2-25$
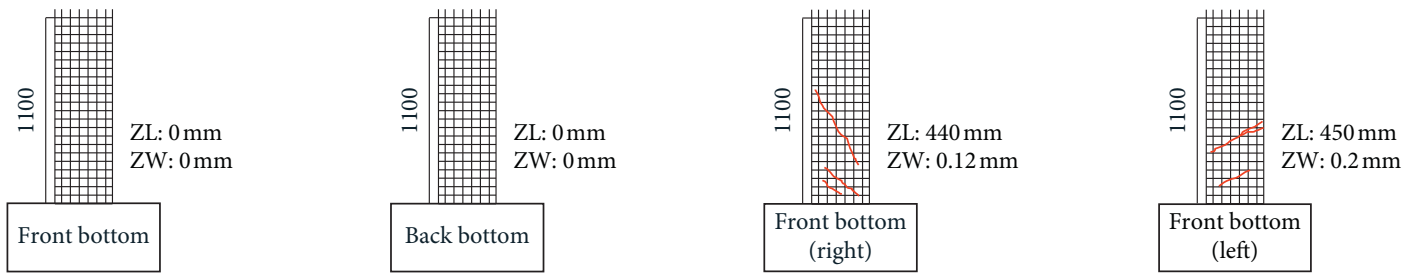

TABLE 12: Number, length, and maximum width of cracks in the lower area of the front of the specimens under different energies.

\begin{tabular}{|c|c|c|c|c|c|c|c|c|c|c|c|c|}
\hline \multirow{3}{*}{ Height of drop hammer $(\mathrm{m})$} & \multicolumn{6}{|c|}{$1^{\text {st }}$ group } & \multicolumn{6}{|c|}{$2^{\text {nd }}$ group } \\
\hline & \multicolumn{2}{|c|}{$\begin{array}{l}\text { Number of } \\
\text { cracks }\end{array}$} & \multicolumn{2}{|c|}{$\begin{array}{l}\text { Lengths of the } \\
\text { main cracks } \\
(\mathrm{mm})\end{array}$} & \multicolumn{2}{|c|}{$\begin{array}{l}\text { Widths of the } \\
\text { main cracks } \\
(\mathrm{mm})\end{array}$} & \multicolumn{2}{|c|}{$\begin{array}{l}\text { Number of } \\
\text { cracks }\end{array}$} & \multicolumn{2}{|c|}{$\begin{array}{l}\text { Lengths of the } \\
\text { main cracks } \\
(\mathrm{mm})\end{array}$} & \multicolumn{2}{|c|}{$\begin{array}{l}\text { Widths of the } \\
\text { main cracks } \\
(\mathrm{mm})\end{array}$} \\
\hline & S1-16 & $\mathrm{Z} 2-20$ & S1-16 & $\mathrm{Z} 2-20$ & S1-16 & $\mathrm{Z} 2-20$ & $\mathrm{~S} 1-20$ & $\mathrm{Z} 2-25$ & S1-20 & $\mathrm{Z} 2-25$ & S1-20 & $\mathrm{Z} 2-25$ \\
\hline 2 & 0 & 0 & 0 & 0 & 0 & 0 & 0 & 0 & 0 & 0 & 0 & 0 \\
\hline 4 & 0 & 0 & 0 & 0 & 0 & 0 & 0 & 0 & 0 & 0 & 0 & 0 \\
\hline 6 & 0 & 0 & 0 & 0 & 0 & 0 & 0 & 0 & 0 & 0 & 0 & 0 \\
\hline 8 & 0 & 1 & 0 & 406 & 0 & 0.21 & 0 & 1 & 0 & 270 & 0 & 0.09 \\
\hline 10 & 1 & 2 & 400 & 520 & 0.15 & 0.31 & 1 & 2 & 380 & 400 & 0.11 & 0.12 \\
\hline 12 & 2 & 3 & 460 & 600 & 0.52 & 0.67 & 2 & 3 & 450 & 430 & 0.2 & 0.17 \\
\hline
\end{tabular}

specimen and continue to develop with the increase of impact energy. The second group of specimens (S1-20/Z225 ) is dominated by shear failure without horizontal cracks but forms main oblique cracks of about $45^{\circ}$ along the damaged surface, and the development of the cracks is similar to typical shear cracks found in nature. The key to the failure of members is the shear action under the impact load. The failure is controlled by an oblique shear crack which develops from the reinforced concrete column foundation toward the main diagonal direction, while the failure surface extends from the bottom of the impact back to the top. Table 12 shows the number, length, and maximum width of cracks in the lower area of the front of the specimen under different energies.

It can be seen from Table 12 that with the increase of impact energy, the change trend of the crack number, length, and width of equal-strength replacement specimen remains consistent. In addition, under the same impact energy, the crack number, length, and main crack width of concrete pier after equal-strength replacement with stainless steel reinforcement are relatively approximate to each other.

\section{Conclusion}

In this paper, two groups of specimens of reinforced concrete bridge piers are studied via horizontal impact tests. Through the analysis of the recorded results of failure mode, crack development process, impact force, displacement time history, and concrete damage of reinforced concrete bridge piers under different impact speeds, impact energies, and multiple impacts, the following conclusions are obtained:

(1) Under the protection of closed-cell aluminum foam, the impact force of S1-16 is greater than that of Z2-20 when the specimen is dominated by bending failure (such as in the first group) before and after the equal-strength replacement with stainless steel. Due to the fact that the ductility of 
the ordinary steel bar is greater than that of the stainless steel bar and that the stainless steel has greater strength and toughness, the overall stiffness of the specimen is improved. Furthermore, when the specimen is dominated by shear failure (such as in the second group), the impact force of S1-20 is smaller than that of Z2-25. Due to the fact that the shear failure is dominated by the staggered deformation of the concrete section and that the section bending rigidity of the ordinary reinforced concrete pier is slightly greater than that of the stainless steel concrete pier, it is evident that the impact force is not only related to the overall stiffness but also to the failure mode of the specimen.

(2) In the first stage, when the impact velocity is less than $1.42 \mathrm{~m} / \mathrm{s}$, the closed-cell aluminum foam is in the elastic or yielding stage. The change rate of impact force of the two groups of specimens is smaller (231 and 97.5), and the respective relative ratio of impact force is stable at $26 \%$ and $21 \%$. When the change rates of the top displacement are 33.5 and 18 , the strain of reinforcement and ultrasonic damage of concrete is small. In general, the impact effect and dynamic response change rule of the two groups of specimens are approximately equivalent.

(3) In the second stage, when the impact is greater than $1.42 \mathrm{~m} / \mathrm{s}$, the closed-cell aluminum foam is in the densification stage, and the change rate of impact force of the two groups of specimens is greater (from 231 to 819 and from 97.5 to 984.5 ), and the relative ratio of impact force decreases (from $26 \%$ to $9 \%$ and from $21 \%$ to $7 \%$ ). The change rates of the top displacement (from 33.5 to 67 and from 18 to 62 ) and ultrasonic damage of concrete of the two groups are both greater, which will increase the dynamic response of the structure. The effect of closed-cell aluminum foam densification on the ordinary reinforced concrete members is greater than that on the stainless steel reinforced concrete members. By increasing their thickness, the aluminum foam will be delayed from entering the densification stage to a certain extent.

(4) Based on the damage mode of concrete and specimen, it can be seen that, under the protection of closed cell aluminum foam, the failure modes of both, as well as the crack number and distribution and concrete damage, are approximately consistent before and after the equal-strength replacement of stainless steel. Moreover, the lateral deformation of pier impact is smaller after the equal-strength replacement with stainless steel reinforcement.

\section{Data Availability}

The test data are included within the article and can be made freely available.

\section{Conflicts of Interest}

The authors declare that there are no conflicts of interest regarding the publication of this paper.

\section{Acknowledgments}

This study was sponsored by the Major Project (Natural Science) of Department of Education of Guangdong Province (2014KZDXM064), the Science and Technology Innovation Project of Department of Education of Guangdong Province (2013KJCX0188), and the Civil Engineering Technology Research Center of Guangdong Province.

\section{References}

[1] InCom Working Group 19, Ship Collision Due to the Presence of Bridges, Report of Working Group 19 of the, Inland Navigation Commission, Brussels, Belgium, 2001.

[2] B. Yan and G. L. Dai, "Investigation and countermeasures of ship-bridge collision accidents in China in recent years," Advanced Materials Research, vol. 168-170, pp. 167-174, 2010.

[3] L. Fang, L. Zhang, S. M. Yan, N. Jia, M. Jing, and L. Ma, "Design optimization and safety evaluation of cross-sea bridge barrier," Applied Mechanics and Materials, vol. 97-98, pp. 100-107, 2011.

[4] H. M. I. Thilakarathna, D. Thambiratnam, M. Dhanasekar, and N. Perera, "Shear-critical impact response of biaxially loaded reinforced concrete circular columns," ACI Structural Journal, vol. 110, no. 4, pp. 565-574, 2013.

[5] J. Hong, Y.-H. Chen, and G.-H. Wu, "Acting forces and energy transformation characteristics of anti-collision idler pulley for bridge pier under colliding," Journal of PLA University of Science and Technology (Natural Science Edition), vol. 13, 2012.

[6] M.-Si QI, J.-Ning Zhang, W. Yang et al., "Research on shock cushing performance of foamed aluminium polyurethane composite structure," Packaging Engineering, vol. 31, no. 19, pp. 6-9, 2010.

[7] M. Saadatfar, M. Mukherjee, M. Madadi et al., "Structure and deformation correlation of closed-cell aluminium foam subject to uniaxial compression," Acta Materialia, vol. 60, no. 8, pp. 3604-3615, 2012.

[8] U. E. Ozturk and G. Anlas, "Energy absorption calculations in multiple compressive loading of polymeric foams," Materials \& Design, vol. 30, no. 1, pp. 15-22, 2009.

[9] J. Fan, K. Xin et al., "Experimental study of quasi-static mechanical characteristic of polyurethane foam material," Joural of Experiment Mechanics, vol. 26, no. 2, pp. 139-145, 2011.

[10] A. Q. Li, T. Zhang, L. L. Jie et al., "Experimental study on the mechanical behavior of closed-cell aluminum foam with high porosity under compression," Journal of Beijing University of Civil Engineering and Architecture, vol. 33, pp. 1-6, 2017.

[11] X. G. Wang, Y. M. Zhang, Y. P. Su, and Y. Feng, "Experimental investigation on the effect of reinforcement ratio to capacity of RC column to resist lateral impact loading," Systems Engineering Procedia, vol. 1, pp. 35-41, 2011.

[12] Li. Tian, C. Zhu, H. Wang, and X.-H. Feng, "Dynamic response and failure modes of RC columns under impact," Engineering Mechanics, vol. 30, no. 2, pp. 150-155, 2013. 
[13] G. Zhang, S. Xu, H. Xie, X. Zhou, and Y. Wang, "Behavior of stainless steel-reinforced concrete piers under lateral impact loading," Advances in Mechanical Engineering, vol. 9, no. 5, Article ID 168781401770993, 2017.

[14] X. Zhou, Y. Gao, G. Zhang, and S. Xu, "An experimental research of mechanical properties of the impacts of equalstrength stainless reinforced replacement piers," Advances in Mechanical Engineering, vol. 3, no. 5, pp. 101-108, 2018.

[15] Y. S. Yang, Z. Yang, K.-H. Yu, B. Liang, and X.-G. Kang, "Study on the cushioning property and deformation failure mechanism of close-cell aluminum foam," Journal of Functional Materials, vol. 45, no. 8, pp. 08087-08091, 2014.

[16] S. Q. Shi, J. G. Kang, and S. B. Sui, "Experimental study of quasi-static and dynamic compressive property of close-cell aluminum foam," Rare Metal Materials and Engineering, vol. s2, pp. 150-154, 2011.

[17] L. J. Gibson and M. F. Ashby, Cellular Solids: Structure and Properties, Cambridge University Press, Cambridge, UK, 1997.

[18] H. J. Yu, B. Li, Z.-Q. Guo, and G.-C. Yao, "Dynamic compressive property of closed-cell aluminum foam with $\mathrm{Al}$ matrix and Al-6Si matrix," Zhongguo Youse Jinshu Xuebao/ Chinese Journal of Nonferrous Metals, vol. 17, no. 5, pp. 704-709, 2007.

[19] G. Reyes, "Static and low velocity impact behavior of composite sandwich panels with an aluminum foam core," Journal of Composite Materials, vol. 42, no. 16, pp. 1659-1670, 2008.

[20] Z. Fan-Bo, L. Feng-Chong, C. Ji-Qing et al., "Experimental analysis on influence factors of energy absorption of aluminum foam structures," Machinery Design \& Manufacture, vol. 9, pp. 14-18, 2014.

[21] L. R. Alejano, H. W. Stockhausen, E. Alonso, F. G. Bastante, and P. R. Oyanguren, "ROFRAQ: a statistics-based empirical method for assessing accident risk from rockfalls in quarries," International Journal of Rock Mechanics and Mining Sciences, vol. 45, no. 8, pp. 1252-1272, 2008.

[22] Z. X. Li, M. X. Zhang, and Y. C. Shi, "Tests for dynamic compressive performance of closed-cell aluminum foams," Journal of Vibration and Shock, vol. 36, no. 5, pp. 1-6, 2017.

[23] B. C. Li, G. P. Zhao, and T. J. Lu, "Low strain rate compression behavior of high porosity closed-cell aluminum foams," Chinese Journal of Theoretical and Applied Mechanics, vol. 43, pp. 122-135, 2011.

[24] F. Lan, F. B. Zeng, Y. J. Zhou et al., "Progress on research of mechanical properties of closed-cell aluminum foams and its applications in automobile crashworthiness," Journal of Mechanical Engineering, vol. 50, no. 22, pp. 97-112, 2014.

[25] G. Sun, E. Wang, J. Zhang, S. Li, Y. Zhang, and Q. Li, "Experimental study on the dynamic responses of foam sandwich panels with different facesheets and core gradients subjected to blast impulse," International Journal of Impact Engineering, vol. 135, Article ID 103327, 2020.

[26] E. Wang, Q. Li, and G. Sun, "Computational analysis and optimization of sandwich panels with homogeneous and graded foam cores for blast resistance," Thin-Walled Structures, vol. 147, Article ID 106494, 2020.

[27] G. Sun, E. Wang, H. Wang, Z. Xiao, and Q. Li, "Low-velocity impact behaviour of sandwich panels with homogeneous and stepwise graded foam cores," Materials \& Design, vol. 160, pp. 1117-1136, 2018.

[28] Z. Nan, X. U. Qi, L. Zhao et al., "Experimental research on effect of buffer on impact performance of reinforced concrete pier," Journal of Highway and Transportation Research and Development, vol. 26, no. 12, pp. 83-90, 2009.
[29] D. F. Xu, Application of Aluminum Foam Protection Device in Bridge Pier Collision Avoidance, Chongqing, Jiaotong University, Chongqing, China, 2006.

[30] Q. M. Li, I. Magkiriadis, and J. J. Harrigan, "Compressive strain at the onset of densification of cellular solids," Journal of Cellular Plastics, vol. 42, no. 5, pp. 371-392, 2006. 